\title{
CCL17/TARC and CCR4 expression in Merkel cell carcinoma
}

\author{
Kashif Rasheed ${ }^{1}$, Ibrahim Abdulsalam¹, Silje Fismen², Øystein Grimstad³, Baldur \\ Sveinbjørnsson $^{1}$ and Ugo Moens ${ }^{1}$ \\ ${ }^{1}$ Molecular Inflammation Research Group, Department of Medical Biology, Faculty of Health Sciences, University of Troms $\emptyset$, \\ N-9037, Tromsø, Norway \\ ${ }^{2}$ Department of Pathology, University Hospital of Northern Norway, N-9038, Tromsø, Norway \\ ${ }^{3}$ Department of Dermatology, University Hospital of Northern Norway, N-9038, Tromsø, Norway \\ Correspondence to: Kashif Rasheed, email: kashif.rasheed@uit.no \\ Keywords: Merkel cell carcinoma; inflammation; cytokines; CCL17/TARC; CCR4 \\ Received: January 29, $2018 \quad$ Accepted: July 12, $2018 \quad$ Published: July 31, 2018 \\ Copyright: Rasheed et al. This is an open-access article distributed under the terms of the Creative Commons Attribution License \\ 3.0 (CC BY 3.0), which permits unrestricted use, distribution, and reproduction in any medium, provided the original author and \\ source are credited.
}

\section{ABSTRACT}

Merkel cell carcinoma (MCC) is a rare, highly aggressive neuroendocrine skin cancer. In more than $\mathbf{8 0} \%$ of the cases, Merkel cell polyomavirus (MCPyV) is a causal factor. The oncogenic potential of MCPyV is mediated through its viral oncoproteins, large $T$ antigen (LT) and small $t$ antigen (ST). To investigate the role of cytokines in MCC, a PCR array analysis for genes encoding inflammatory cytokines and receptors was performed on MCPyV-negative and MCPyV-positive MCC cell lines, respectively. We detected an increased expression of CCL17/TARC in the MCPyV-positive MKL2 cell line compared to the MCPyV-negative MCC13 cell line. Transfection studies in MCC13 cells with LT expression plasmid, and a luciferase reporter plasmid containing the CCL17/ TARC promoter, exhibited stimulated promoter activity. Interestingly, the ectopic expression of CCL17/TARC upregulated MCPyV early and late promoter activities in MCC13 cells. Furthermore, recombinant CCL17/TARC activated both the mitogenactivated protein kinase and the NF-KB pathways. Finally, immunohistochemical staining on human MCC tissues showed a strong staining of CCL17/TARC and its receptor CCR4 in both LT-positive and -negative MCC. Taken together, CCL17/TARC and CCR4 may be a potential target in MCC therapy providing MCC patients with a better overall survival outcome.

\section{INTRODUCTION}

Merkel cell carcinoma (MCC) is a rare, highly aggressive neuroendocrine skin cancer [1, 2]. In 2008, using digital transcriptome subtraction, a new virus belonging to the family of Polyomaviruses, and hence named Merkel cell polyomavirus (MCPyV), was identified in MCC. Worldwide studies have shown that approximately $80 \%$ of all examined MCC contain clonal integrated MCPyV DNA [3], thus indicating that MCPyV is associated with the etiology of MCC $[4,5]$. MCPyV has a circular, double-stranded DNA genome of approximately $5.4 \mathrm{~kb}[6]$. The viral genome possesses the typical polyomavirus tripartite organization, with an early region encoding the regulatory proteins large $\mathrm{T}$ (LT) antigen and small $\mathrm{T}$ (sT) antigen [7], the late region encoding the capsid proteins [8], and a noncoding control region encompassing the origin of replication and transcription regulatory elements [9]. In addition, the early region encodes the 57kT antigen and a protein called alternative LT ORF (ALTO), although their function remains unknown [7]. All MCPyV-positive $(\mathrm{MCPyV}+) \mathrm{MCC}$ express a C-terminal truncated form of LT antigen that has lost its DNA binding and p53 interaction domains, but retains the ability to interact with retinoblastoma protein $\mathrm{pRb}$ [10]. Both sT and fulllength LT, as well as truncated LT, have been shown to possess oncogenic potential in both cell culture and 
animal models [11-14]. The proliferation of MCC cell lines depends on the expression of LT [15], while the role of sT has been disputed $[16,17]$.

Inflammation has long been associated with tumor progression [18]. Many cancers arise from sites of infection, chronic irritation and inflammation, and inflammatory signaling pathways are often activated by oncogenic mutations [19]. Chemokines are a family of cytokines that regulate leukocyte trafficking in immunity and inflammation, playing a significant role in processes attributed to tumorigenesis, such as tumor cell survival, senescence, angiogenesis, metastasis and immune escape. The aberrant expression of chemokines and chemokine receptors in tumors may regulate the trafficking of leukocytes into the tumor microenvironment [20]. Chemokines secreted within the tumor microenvironment may also act in an autocrine manner to promote the proliferation and migration of the tumor cells. Chemokine (C-C motif) ligand 17/thymus and activation-regulated (CCL17/ TARC) is a member of the CC chemokine family, and is highly expressed by thymus and other cells, including keratinocytes, endothelial cells, dendritic cells, bronchial epithelial cells and fibroblasts [21]. CCL17/ TARC acts as a chemoattractant, which primarily aids the recruitment of $\mathrm{CD}_{4}^{+} \mathrm{T}$ regulatory cells and $\mathrm{Th} 2$, in addition to Th17 cells [22, 23]. The effect of CCL17/ TARC is mediated by the chemokine receptor CCR4 $[24,25]$.

In this study we compared the cytokine expression pattern in MCPyV-positive with MCPyV-negative MCC cells and examined the role of the viral protein LT on cytokine expression. In addition, we investigated whether cytokines have an impact on viral expression.

\section{RESULTS}

\section{Differential expression profile of inflammatory modulators in MCPyV-negative and MCPyV- positive MCC cell lines}

Inflammatory mediators such as cytokines are known to play a role in cancer. This prompted us to compare the expression of 84 inflammatory cytokines and cytokine receptors in a $\mathrm{MCPyV}$-negative (MCC13) and a MCPyV-positive MCC cell line (MKL-2), respectively. All 84 human inflammatory cytokines and receptor transcripts were detectable $(\mathrm{Cq}<35)$ by RT profiler PCR array. Out of 84 transcripts, with the fold changes critical value set $\geq 2$ fold differentiated, the expression of $11(13.09 \%)$ were upregulated and the expression of 18 $(21.42 \%)$ were downregulated in MKL-2 cells compared with MCC13 cells, while 55 (65.47\%) of the genes had comparable transcription levels in both cell lines (Figure 1A) (data not shown).

\section{Expression analysis of cytokines and their receptor in MCPyV-negative MCC13 cells and MCC13 cells transiently expressing exogenous LT}

Because the LT of polyomaviruses is known to affect viral and cellular gene expression (30), we wanted to examine whether LT may be responsible for the differential expression of cytokines and their receptors in these MCC cell lines [10, 26]. Therefore, the eukaryotic expression vectors for MKL-2 LT, but also for the LT of two other virus-positive MCC cell lines (MKL-1 and MS-1), were generated. These virus-positive expression plasmids containing full-length LT and truncated LT (MKL-1, MKL-2 and MS-1) were then confirmed by sequencing (Supplementary Figure 1). A Western blot of lysates from MCC13 cells transfected with these expression plasmids confirmed the presence of LT with a correct predicted molecular mass (Supplementary Figure 2). Next, we transfected MCC13 cells with pcDNA3-fulllength LT, pcDNA3-MKL-2, or empty vector pcDNA3 as a control, and measured the transcript levels of the 84 inflammatory cytokines and receptors by qPCR. For cells transfected with full-length LT expression plasmid, 71 out of 84 human inflammatory cytokines and receptor transcripts were detectable $(\mathrm{Cq}<35)$, whereas the transcript for the remaining 13 genes was undetectable or had Cq values $\geq 35$ by RT profiler PCR array. Out of 84 transcripts, with the fold changes critical value set $\geq$ 2, $8(9.52 \%)$ genes were upregulated, while $76(90.48 \%)$ genes did not show any effect or undetectable compared with empty vector transfected cells (Figure 1B) (data not shown). For cells transfected with MKL-2 truncated LT expression plasmid, 70 out of 84 human inflammatory cytokines and receptor transcripts were detectable $(\mathrm{Cq}$ $<35$ ), while of the remaining, 14 were undetectable or had $\mathrm{Cq}$ values $\geq 35$ by RT profiler PCR array. Out of 84 transcripts, with the fold changes critical value set $\geq$ 2, $32(38.09 \%)$ genes were upregulated and $4(4.76 \%)$ genes were downregulated, while 48 (57.14\%) genes did not show any effect or undetectable compared with the control cells (data not shown) compared to MCC13 cells transfected with an empty vector (Figure 1C). One of the genes whose transcript levels were consistently upregulated in MKL-2 cells, and in MCC13 cells transiently expressing full-length or truncated MKL-2 LT compared to MCC13 cells, was CCL17/TARC.

\section{MCPyV large T antigen induces CCL17/TARC promoter activity}

Because CCL17/TARC expression was shown to be upregulated in cells that were either MCPyV-positive or that expressed a full-length or truncated LT, we tested whether MCPyV LT could induce CCL17/TARC promoter 
activity. For this purpose, MCC13 cells were transiently co-transfected with a plasmid encoding a full-length or truncated LT (MKL-1, MKL-2 and MS-1), and with a luciferase reporter driven by different fragments of the CCL17/TARC promoter (fragment -2535/+ 40, -1084/+ 40 or $-378 /+40$, respectively). The empty vector pcDNA3 was used as a control. Full-length, as well as the truncated LT versions MKL-1 and MS-1 significantly stimulated the CCL17/TARC promoter activity. The largest CCL17/ TARC promoter fragment $(-2535 /+40)$ was more potently activated than the shorter promoter fragments $(-1084 /+40$ and $-375 /+40$, respectively) by LT MKL-1 and MS-1, while comparable full-length LT-mediated transactivation the three different CCL17/TARC promoter fragments. MKL-2 LT significantly stimulated the activity of the CCL17/TARC promoter encompassing nucleotides $-2535 /+40$ and $-375 /+40$, but induced only slightly, but statistically insignificant the CCL17/TARC -1080/+40 promoter sequence (Figure 2). These results confirm the qPCR data showing that CCL17/TARC expression is higher in LT expressing MCC13 compared to MCC13 cells. The enhanced CCL17/TARC transcript levels in MKL-2 cells, compared to the virus-negative MCC13 cells, may at least be partially triggered by LT. In contrast,
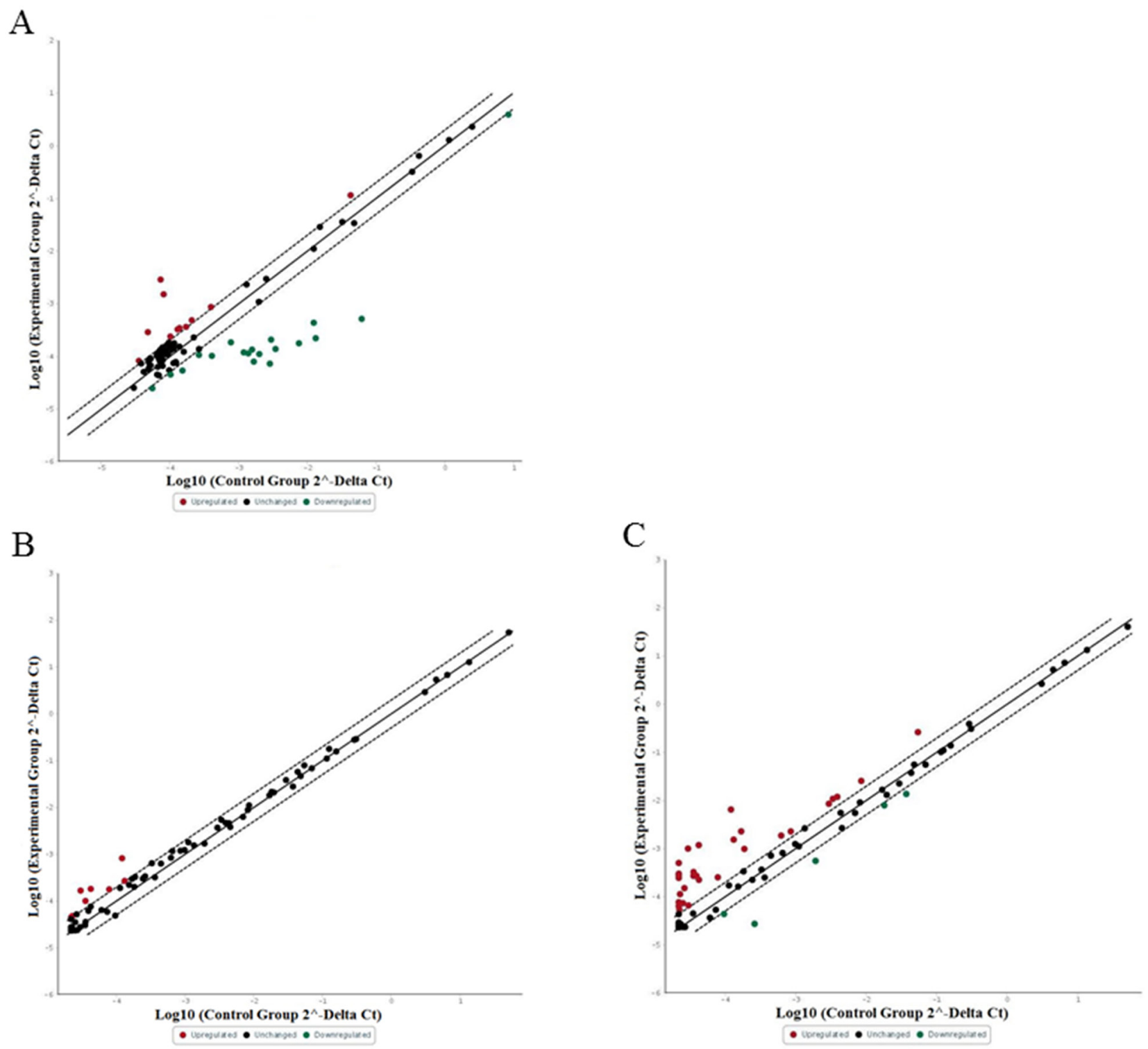

Figure 1: Relative expression comparison of 84 inflammatory cytokines and receptors genes between MCPyVassociated and non-associated Merkel cell carcinoma. The figures depict a log transformation plot of the relative expression level of each gene (2-4Ct) between (A) MCC13 cells vs. MKL-2 cells, (B) full-length LT vs. empty vector transfection in MCC13 cell line and (C) MKL-2 truncated LT vs. empty vector transfection in MCC13 cell line. The dotted lines indicate a two-fold change in gene expression threshold. 
sT did not stimulate the activity of any of the CCL17 promoter fragments or increase sT protein levels when expressed in MCC13 cells (results not shown).

\section{CCL17/TARC ectopic effect on MCPyV early and promoter activity}

Cytokines such as IL-1 $\beta$, TGF $\beta$ and TNF- $\alpha$ have been shown to stimulate the activity of human polyomavirus promoters [27-30]. Therefore, we investigated whether CCL17/TARC could exert an effect on the MCPyV early and late promoter activity. MCC13 cells were transfected with a luciferase reporter plasmid containing, either the early or late MCPyV promoter, and cells were either cotransfected with a CCL17/TARC expression plasmid or treated with recombinant human CCL17/TARC protein. Both an ectopic expression of CCL17/TARC and administering of recombinant CCL17/TARC to cells resulted in a significant upregulation of both the early and late MCPyV promoter activity (Figure 3).

\section{Expression of CCL17/TARC and CCR4 in MCC cells}

To confirm the stimulating effect of full-length and truncated LT on CCL17/TARC promoter activity, we first evaluated the mRNA expression of CCL17/TARC by qPCR in MCC13 cells transfected with expression vector for full-length LT or truncated LT variants. Fulllength and MKL-1 LT significantly increased CCL17/ TARC expression in the MCC13 cell line $(\mathrm{P}<0.01)$, while MKL-2 and MS-1 LT variants, modestly, but significantly increased CCL17/TARC mRNA levels (Figure 4A). Western blot analysis with anti-CCL17/TARC antibodies confirmed that CCL17/TARC protein levels were increased in MCC13 cells expressing either full-length or truncated LT compared to MCC13 cells (Figure 4B and 4D). In our screening experiments, we also found a slight upregulation of CCR 4 mRNA by exogenous expression of both pcDNA3-FLTA and pcDNA3-MKL-2 plasmids. So, to check at the protein level, we conducted a Western blot.

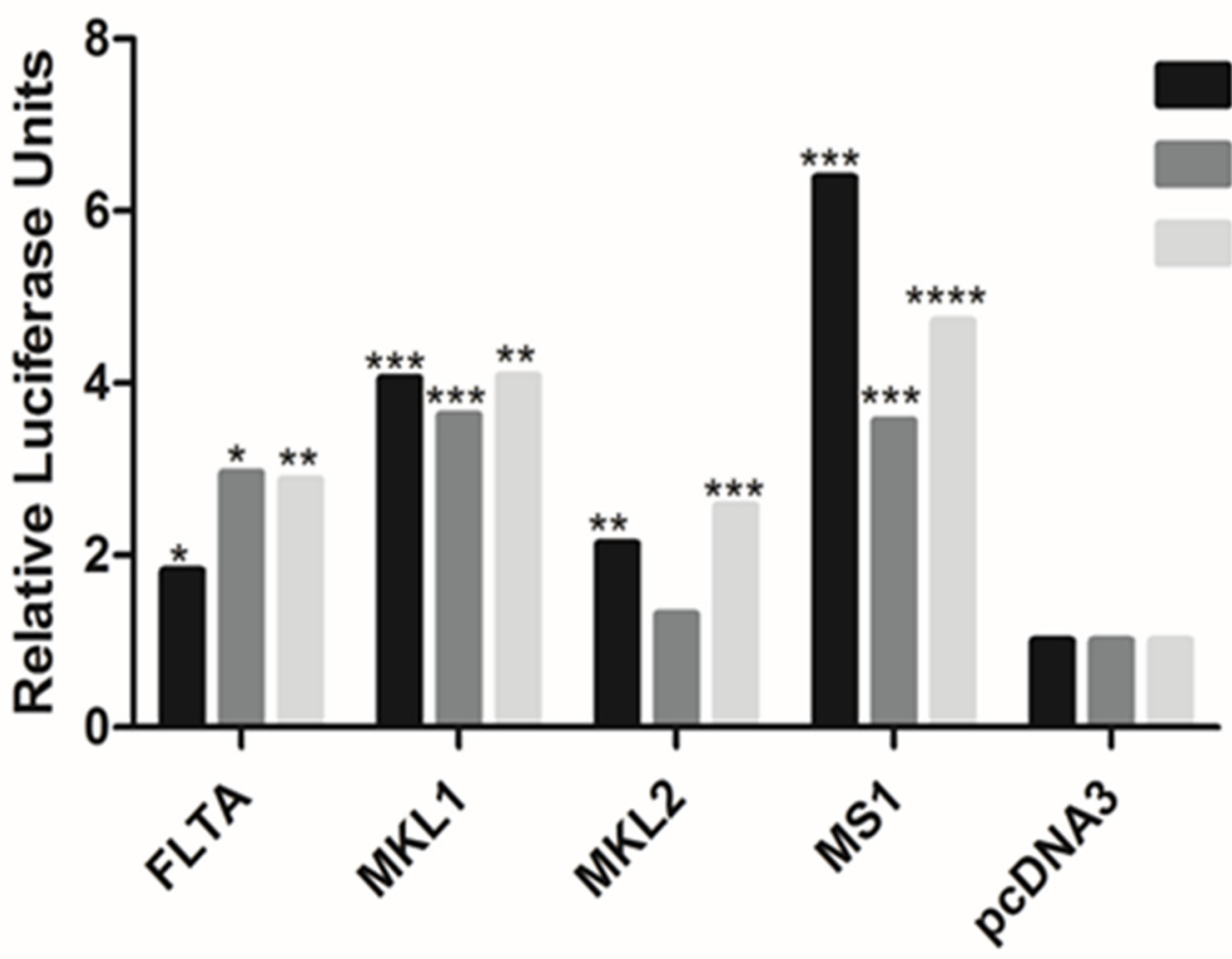

Figure 2: Effect of full-length and truncated (MKL-1, MKL-2 and MS-1) LT on CCL17/TARC promoter activity in MCC13 cells. Cells were transfected with a luciferase reporter vector driven by CCL17/TARC promoter fragments spanning nucleotides $-2535 /+40,-1084 /+40$ or $-375 /+40$, respectively. Expression plasmid for full-length LT (FLTA), MKL-1, MKL2 or MS-1 LT, or pcDNA3 control, were co-transfected. Luciferase activity was assessed after an overnight cultivation of transfected cells. The promoter activity in presence of pcDNA3 was arbitrary set as 1.0 and the promoter activity measured in the presence of LT was related to this. Each bar represents the average of three independent parallels \pm SD. The experiment was repeated two more times, and similar results were obtained. Luciferase values were normalized with a total protein in each sample. $P^{*} \leq 0.05, P^{* *} \leq 0.01, P^{* * *} \leq 0.001$ and $P^{* * * *} \leq 0.0001$. 
We did not find expression at a significant level, but only a slight upregulation of CCR4 in MCC13 cells with an exogenous expression of MCPyV LT (Figure 4C and 4D).

\section{CCL17/TARC activates the mitogen-activated protein kinase (MAP kinase) and NF- $\mathrm{KB}$ pathways in MCC cells}

Both CCL17/TARC and ERK1/2 have been shown to be involved in skin inflammation [31-33], thereby suggesting that CCL17/TARC may activate the MEK1/2ERK1/2 mitogen-activated protein kinase pathway. To help investigate the effect of CCL17/TARC on MEK1/2ERK1/2 activation in MCPyV-associated MCC, we stimulated MCC13 cells with recombinant human CCL17/TARC. The cells were stimulated with different concentrations $(2.5 \mathrm{ng} / \mathrm{ml}$ to $15 \mathrm{ng} / \mathrm{ml})$ and time periods ( $5 \mathrm{~min}$ to $60 \mathrm{~min}$ ) and we monitored the phosphorylation of ERK1/2 using phospho-specific antibodies and western blotting. Activation of ERK1/2 by rhCCL17/TARC was shown to be concentration dependent (Figure 5). The ERK1/2 phosphorylation activity was inhibited by using a specific CCR4 antagonist (C021 dihydrochloride) (Figure $6)$.

Previous studies have indicated that $\mathrm{NF}-\kappa \mathrm{B}$ is a target downstream of CCL17/TARC. We found that CCL17/TARC increased the phosphorylation of NF- $\kappa \mathrm{B} /$ p65 activity in a concentration-dependent manner (Figure 7A, 7B), which was inhibited by using a specific CCR4 antagonist (Figure 7D, 7E). Furthermore, NF- $\kappa \mathrm{B}$ promoter assay confirmed an increased luciferase activity of NF- $\kappa \mathrm{B}$ when cells were co-transfected with pCMV2-CCL17 and $\mathrm{NF}-\kappa \mathrm{B}-\mathrm{luc}$ reporter plasmids (Figure $7 \mathrm{C}$ ).

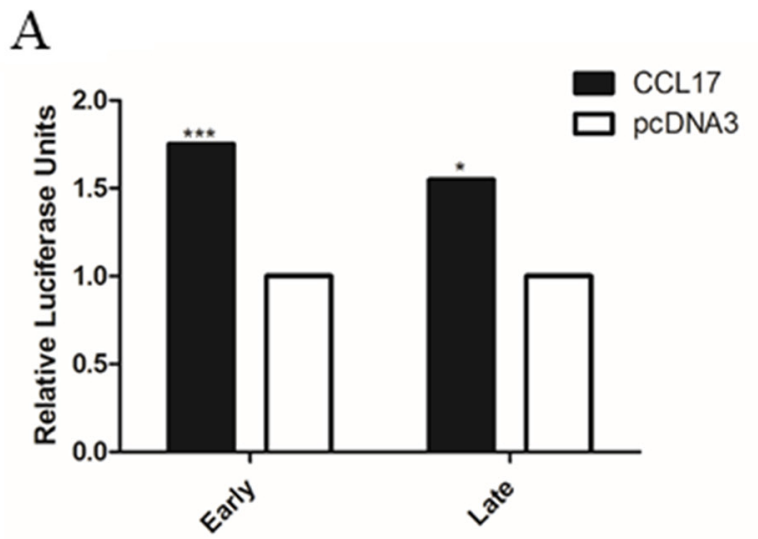

\section{CCL17/TARC stimulates cell proliferation of MCC13 cells}

Next, we examined the effect of rhCCL17/TARC on MCC13 proliferation. A dose-dependent increase in cell proliferation was observed (Figure 7F). The CCR4 antagonist C021 inhibited CCL17/TARC-induced cell proliferation (Figure 7G).

\section{CCL17/TARC and its receptor are expressed in MCC tissue samples}

A total of 23 primary cutaneous MCCs were immunohistochemically stained for LT, CK20, CCL17/ TARC and CCR4, respectively. Fifteen out of 23 (65.2\%) demonstrated an intranuclear positivity consistent with a positivity for LT. All of the 15 LT-positive tumors demonstrated a uniform positivity for CK20 (dot-like cytoplasmic) and CCL17/TARC (dot-like cytoplasmic). With regard to CCR4, 12 out of $15(80 \%)$ of the LTpositive tumors demonstrated cytoplasmic, membranous positivity for CCR4. Of the remaining eight (34.8\%) LT -negative tumors, all of these demonstrated a uniform positivity for CK20, CCL17/TARC and CCR4, respectively (Figure 8).

\section{DISCUSSION}

There is increasing evidence that inflammatory mediators such as chemokines and chemokine receptors are involved in promoting tumor invasion, migration and vascularization [34]. Previous studies have demonstrated the involvement of chemokines, such as CXCL1, CXCL5,
B

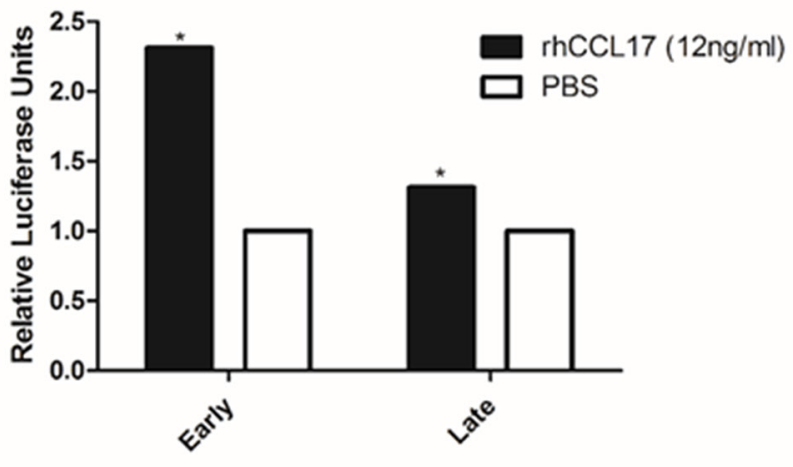

Figure 3: CCL17/TARC stimulates MCPyV early and late promoter activity. (A) MCC13 cells were seeded, and after 24 hrs the cells were serum starved. After serum starvation for $24 \mathrm{hrs}$, the cells were co-transfected with either CCL17/TARC expression plasmid or empty expression vector pcDNA3.1, and luciferase reporter plasmid containing either the MCPyV early or the late promoter. Luciferase activity was measured $24 \mathrm{hrs}$ after transfection. The activity of the MCPyV early (respectively late) promoter in the presence of pcDNA3 was arbitrary set as 1.0 and the activity in the presence of CCL17 was related to this. (B) Cells were transfected as in (A), and were then exposed to rhCCL17/TARC $(12 \mathrm{ng} / \mathrm{ml})$ or vehicle (PBS) for $4 \mathrm{hrs}$ with a subsequent analysis of luciferase activity. Each bar represents the average of three independent parallels $\pm \mathrm{SD}^{*} P<0.05,{ }^{* * *} P<0.001$. 
CXXC4 and IL20RA in MCPyV-associated MCC [35]. In the current study, we performed the screening of different inflammatory cytokines and receptors, and compared their expression in MCPyV LT-positive and -negative $\mathrm{MCC}$, respectively. Other groups have previously reported that LT and ST have an impact on cytokine expression. Ectopic sT expression in MCC13 cells resulted in decreased IL2, IL-8, CCL20 and CXCL9 expression [36]. Also, expression of full-length LT, truncated LT339, and truncated LT339 plus sT in hTERT-immortalized BJ human foreskin fibroblasts increased the expression of IL$1 \beta$, IL-6, IL-8, CXCL1 and CXCL6 [37].

Here we demonstrate that one of the cytokine member whose expression was shown to be significantly enhanced in MCPyV LT-positive cells was CCL17/TARC. CCL17/TARC is a member of CC-motif chemokine family, and is constitutively expressed in thymus and by dendritic cells, endothelial cells, keratinocytes and fibroblasts [38]. An enhanced expression of CCL17/
TARC has been reported in several human malignancies, such as Hodgkin's and B cell lymphoma [39, 40]. Previous studies have revealed that CCL17/TARC possesses several important effects attributed to tumor growth, such as the proliferation [41-43], migration and recruitment of regulatory T-cells [44-46].

We detected a higher expression of CCL17/ TARC in MCPyV-positive MCC compared to MCPyVnegative MCC cells at both the RNA and protein level. Furthermore, by co-transfecting MCC cells with MCPyV full LT, MKL-1 LT, MKL-2 LT and MS-1 LT expression plasmids, as well as CCL17/TARC promoter, resulted in an upregulation of CCL17/TARC promoter activity (Figure 2), which in turn increased the expression of CCL17/TARC (Figure 4). At present, we do not know why the different LT variants activate the CCL17 promoter at different levels. MCPyV full-length LT can interact with several transcription factors including Brd4, the E2F family members 2 and 3, MED14/CRSP2, PRTF1,
A

CCL17/18s
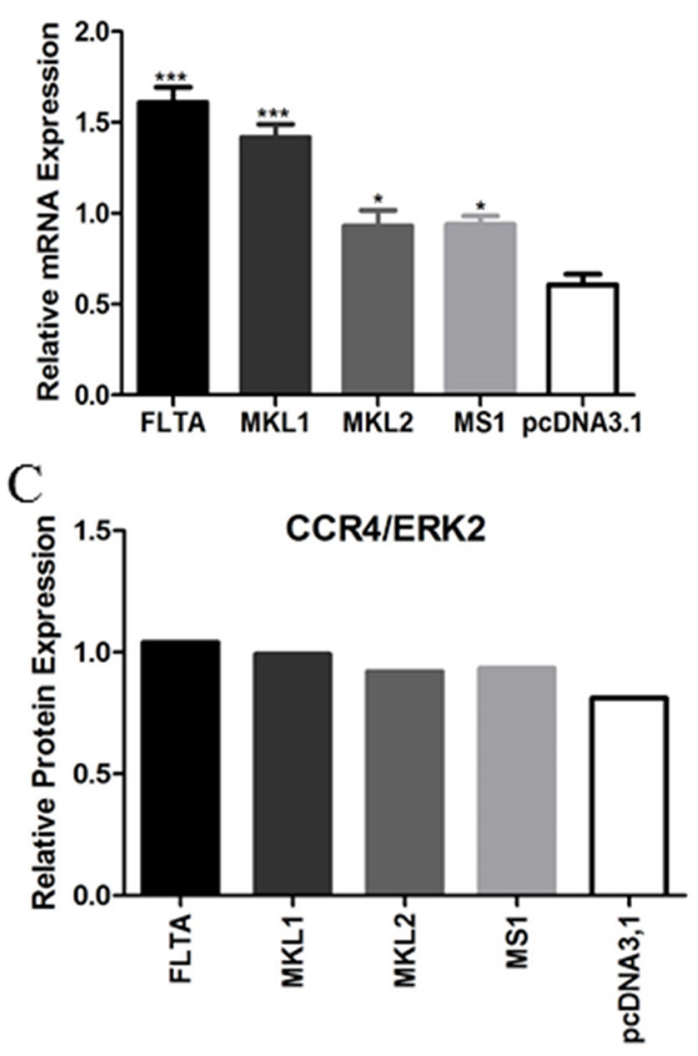

B
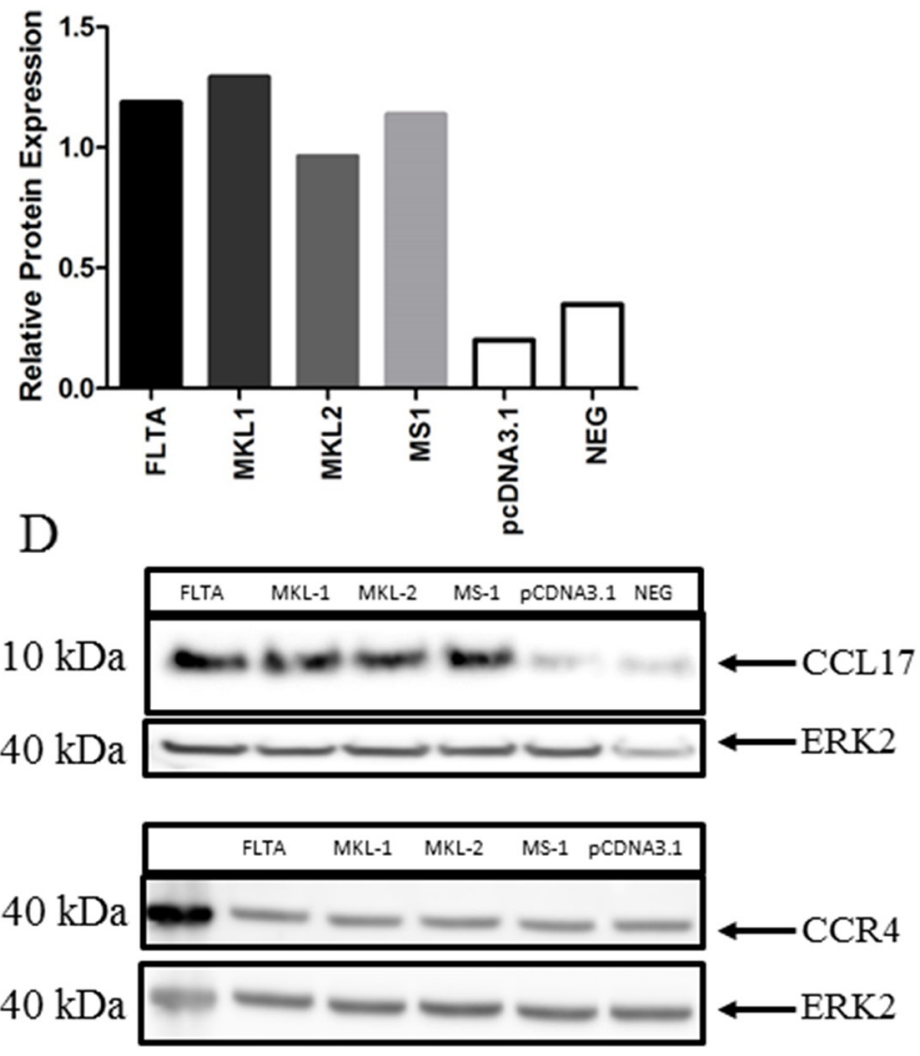

Figure 4: Transient expression of full-length or truncated MCPyV LT increases the transcript and protein levels of CCL17/TARC. MCC13 cells were transfected with an empty vector or expression plasmid for MCPyV full-length LT (FLTA), or truncated MKL-1, MKL-2, or MS-1 LT. (A) qRT-PCR analysis shows CCL17/TARC mRNA levels normalized with eukaryotic 18S rRNA levels. (B) CCL17/TARC protein levels analyzed by Western blotting. The uttermost right lane represents baseline expression of CCL17/ TARC by MCC13 cells. (C) CCR4 protein levels analyzed by Western blotting. A Western blot with ERK2 antibodies was used as a loading control. (D) Representative figures of CCL17/TARC (B) and CCR4 (C) Western blots. The lane most to the left in the lower part contains the protein molecular mass marker (in $\mathrm{kDa}$ ). Bars in $(\mathrm{B})$ and $(\mathrm{C})$ shows a densitometric scanning of the Western blot signals. $P^{*} \leq 0.05$ and $P^{* * *} \leq 0.001$. 
SALL2 and DP1 (see supplementary data in Moens et al. [47]). However, no putative binding sites are present in the CCL17 promoter fragments used in our study. The truncated MCPyV LT variants MKL-1, MKL-2 and MS- 1 retain the $\mathrm{pRb}$ binding motif and may thus relieve the $\mathrm{pRb}$-mediated inhibition of E2F by using $\mathrm{pRb}$. The CCL17/TARC promoter contains the putative GGCGGCA E2F binding site at position -1085/-1079 [48]. This means that our luciferase reporter plasmids containing the CCL17/TARC promoter fragments $-2535 /+40$ and$1084 /+40$ contain this putative E2F binding site. LT may thus activate the CCL17/TARC promoter fragments with an E2F motif by usurping $\mathrm{pRb}$ and releasing the repressive effect on the E2F site. However, the shorter promoter fragment $(-375 /+40)$ which lacks the putative E2F binding site is still trans-activated by LT, indicating that LT-mediated activation seems to be independently of the E2F site. The autocrine release of CCL17/TARC

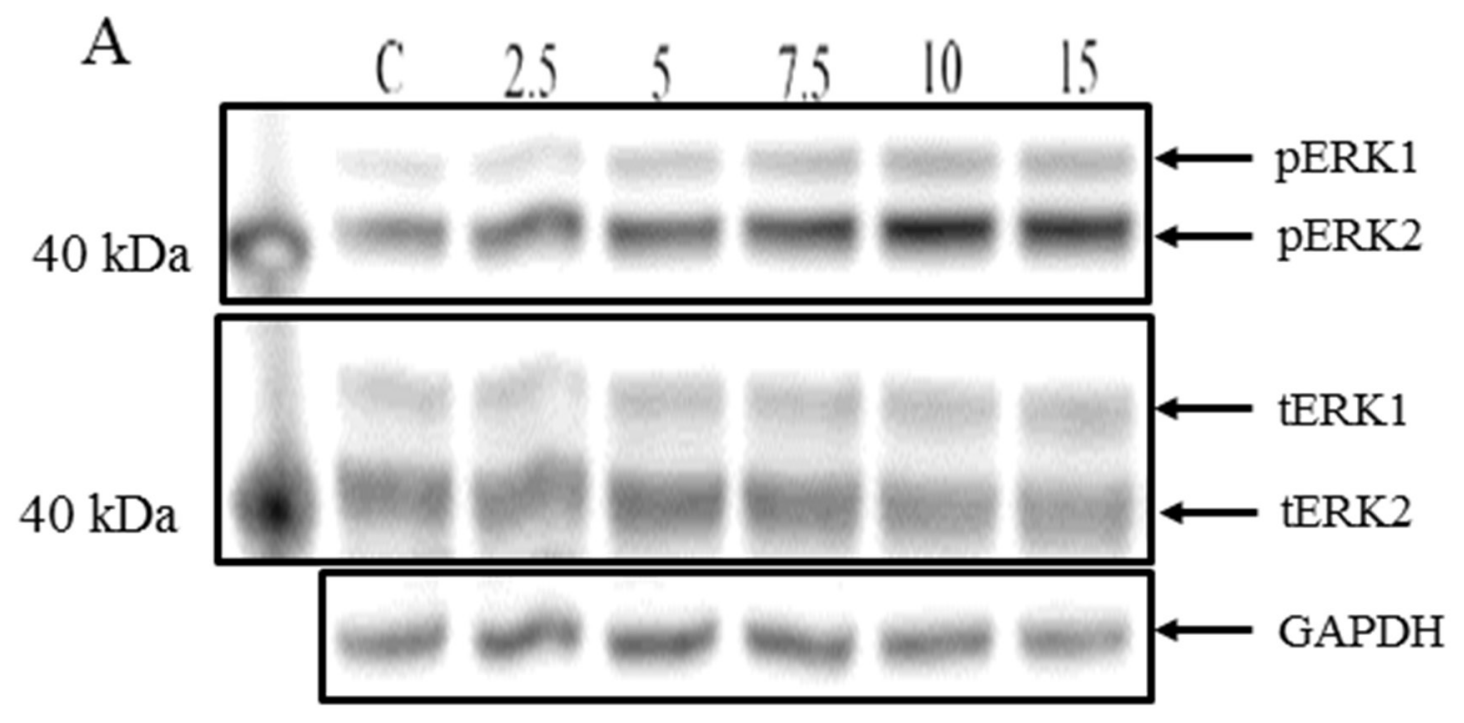

$\mathrm{B}$

\section{pERK1/2/GAPDH}

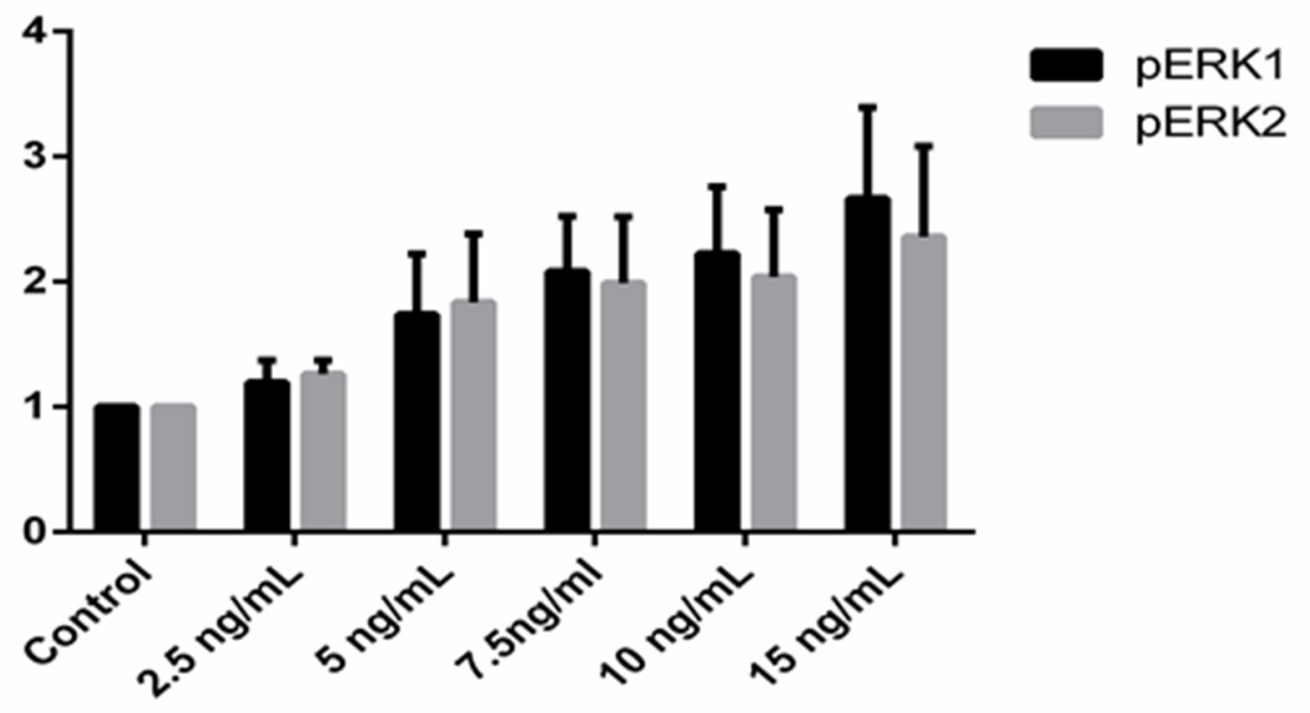

Figure 5: CCL17/TARC upregulates ERK1/2 activity. (A) PhosphoERK1/2 (pERK1/2) expression levels were determined by Western blot analysis using a phospho-specific antibody detecting Thr202/Tyr204 phosphorylation and compared to total ERK1/2 (tERK1/2) levels using an anti-pan-ERK1/2 antibody. MCC13 $\left(1 \times 10^{5}\right)$ cells were seeded in a 6-well plate. Cells were then serum-starved for $24 \mathrm{hrs}$, and thereafter stimulated with either PBS (control or C) or with 2.5, 5, 7.5, 10 and $15 \mathrm{ng} / \mathrm{ml}$ of rhCCL17/TARC for 45 min. (B) Densitometry scanning represent the expression of pERK1 (respectively pERK2) protein relative to GAPDH. 
results in an increase of $\mathrm{MCPyV}$, both in early and late promoter activity, as shown by the overexpression of CCL17 with pCMV2-CCL17-flag plasmid and stimulation with recombinant CCL17/TARC (Figure 3). These data above indicated that MCPyV LT increases CCL17/TARC expression, which results in the replication of $\mathrm{MCPyV}$ and the release of viral oncoproteins, which in turn promotes MCC development. In line with our data, the virusmediated expression of CCL17/TARC has been reported in different types of cells. The Epstein-Barr infection of $\mathrm{B}$ cells induces the expression of CCL17/TARC [49], whereas the respiratory syncytial virus infection of Balb/c mice results in an increased CCL17/TARC production in the lung [50]. Hence, the virulent properties of viruses may depend on their ability to stimulate the expression of CCL17/TARC.
The role of CCR4 in tumor growth and survival has previously been reported. CCR4 is expressed in T-cell leukemia [51], non-lymphoid solid tumors, such as breast cancer, lung cancer, colorectal cancer, gastric and hepatocellular carcinoma [42, 43, 52-56], where it may contribute to the proliferation of tumor cells and chemotaxis of regulatory $\mathrm{T}$ cells $[43,46,53,57]$. Interestingly, an elevated expression of CCR4 in different types of human cancers has been related to a poor prognosis [52, 58-61].

By immunohistochemistry, we detected CCL17/ TARC and its receptor CCR4 in the tumor cells of all MCC tissue samples analyzed. The normal epidermis of the skin was also shown to express CCL17/TARC and CCR4, and has been reported earlier [62-65]. We did not observed any difference in the protein expression

A

$\operatorname{rhCCL} 17++++++++++$ + + $\mathrm{C} 021$

$\begin{array}{cc}+ & + \\ \left(15^{\prime}\right) & \left(15^{\prime}\right)\end{array}$

$\left(30^{\prime}\right)\left(30^{\prime}\right)$

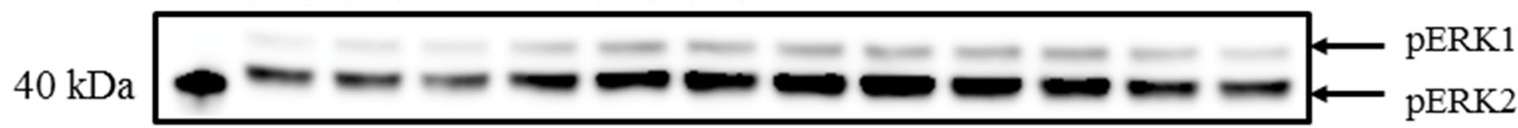

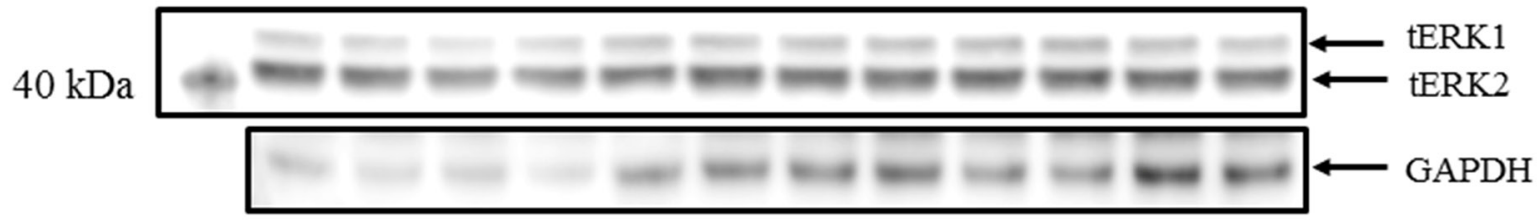

B
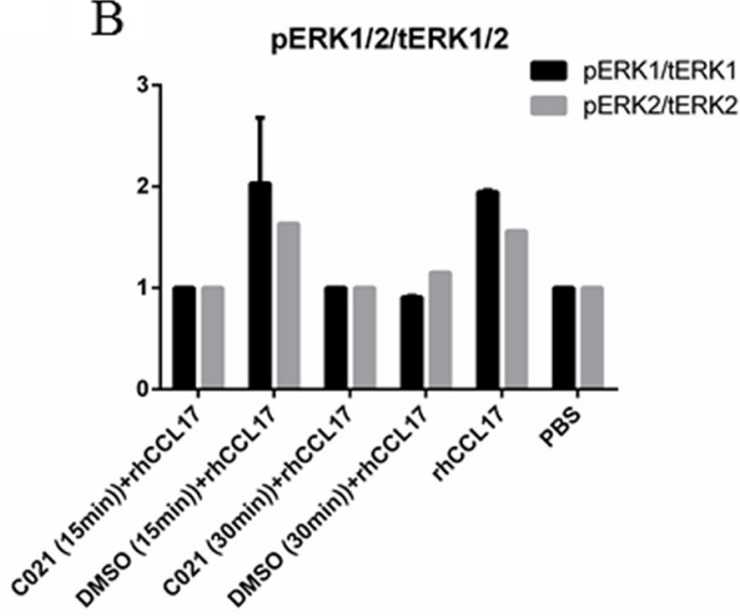

$\mathrm{C}$ pERK1/2/GAPDH

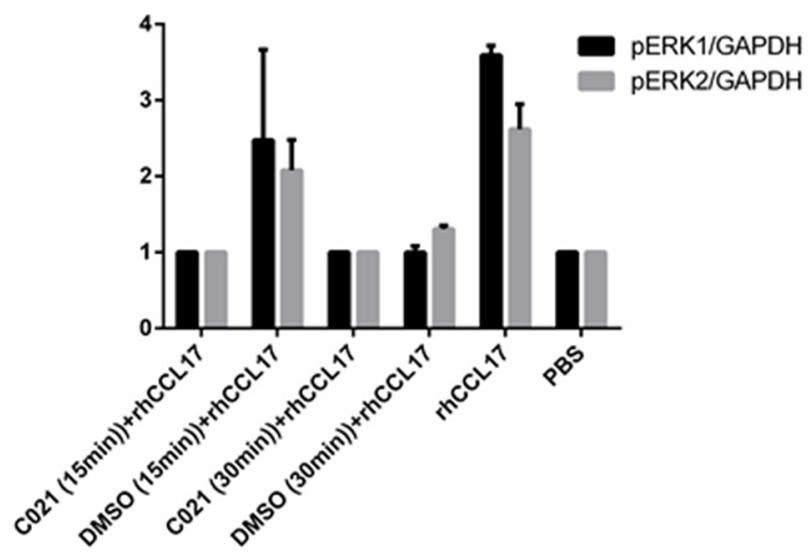

Figure 6: The CCR4 receptor antagonist C021 reduces CCL17/TARC-induced phosphorylation of ERK1/2. (A) MCC13 $\left(1 \times 10^{5}\right)$ cells were seeded in a 6 -well plate and were serum starved for $24 \mathrm{hrs}$. The cells were either pre-exposed to PBS, C021 dihydrochloride $(+)$, a specific CCR4 receptor antagonist, or left untreated (-) for $15 \mathrm{~min}\left(15^{\prime}\right)$ or $30 \mathrm{~min}\left(30^{\prime}\right)$ as indicated. The cells were subsequently incubated with rhCCL17/TARC $(15 \mathrm{ng} / \mathrm{ml})$ or left untreated (-) for another $45 \mathrm{~min}$. Cell lysates were prepared and phosphoERK1/2 and total ERK1/2 levels were monitored. GAPDH levels were used as loading control. Densitometry represents the expression of pERK1 (respectively pERK2) protein relative to (B) total ERK (tERK1/2) and (C) GAPDH. 

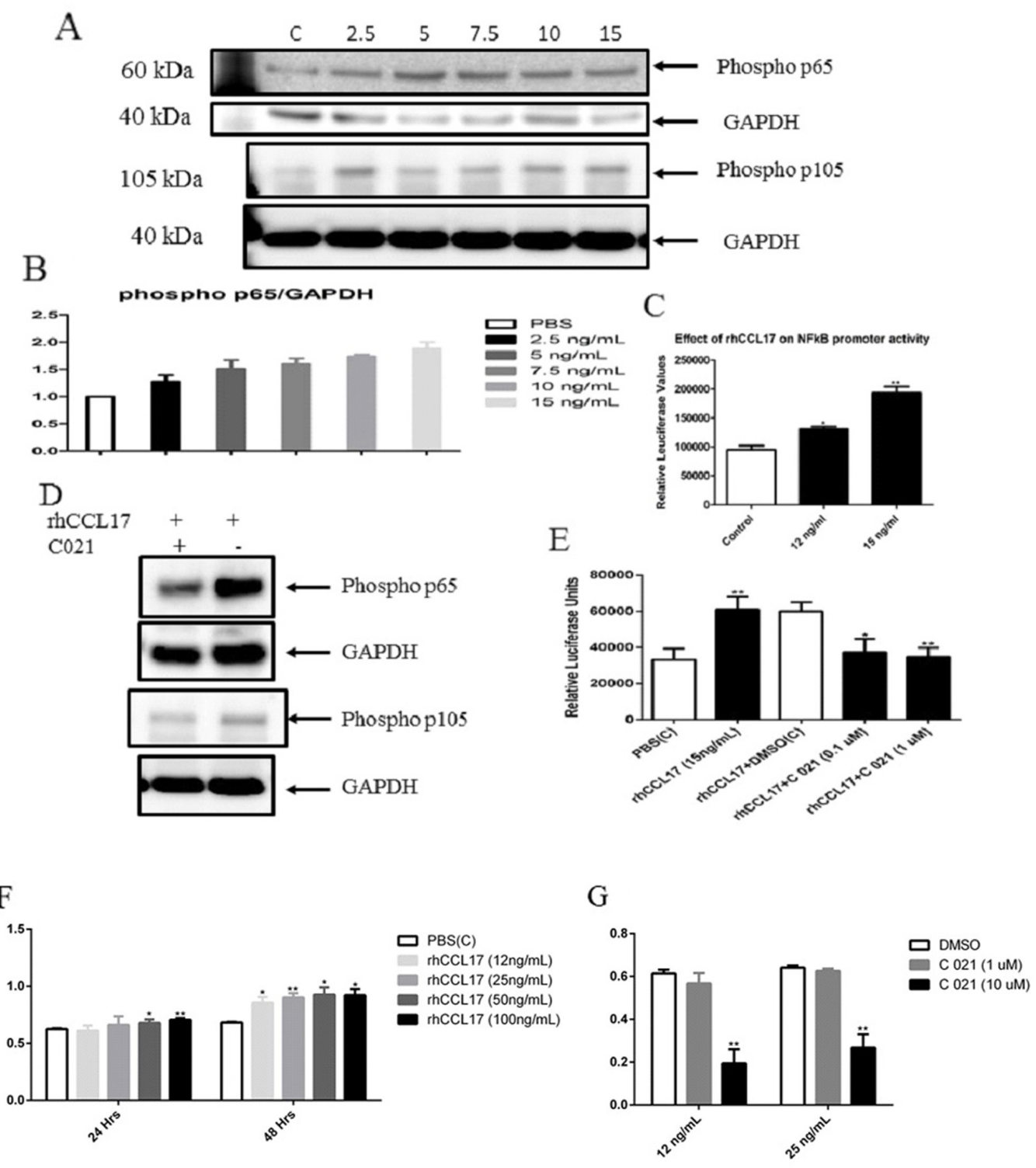

Figure 7: CCL17/TARC upregulated NFKB activity. (A) NFkB-p65 activation was determined by monitoring phosphorylation of $\mathrm{p} 65$ and $\mathrm{p} 105$. MCC13 cells $\left(1 \times 10^{5}\right)$ were seeded in a 6-well plate. Cells were serum starved for $24 \mathrm{hrs}$, and then stimulated with $2.5,5$, $7.5,10$ and $15 \mathrm{ng} / \mathrm{ml}$ of rhCCL17/TARC for $45 \mathrm{~min}$. PBS was used as a control. Relative phospho p65 and phospho p105 were determined by western blot with phosphospecific antibodies. (B) Shows densitometry bars of western blot. (C) NFkB activity was measured by using a luciferase reporter plasmid containing a NFKB-responsive promoter. Cells were stimulated with 12ng/ml or 15ng/ml of rhCCL17/TARC for 4 hrs. Luciferase values were normalized with total protein. (D) The CCR4 receptor antagonist interferes with CCL17/TARC-induced activation of NFKB. Phospop65 and phosphor p105 levels were determined by western blot. MCC13 $\left(1 \times 10^{5}\right)$ cells were seeded in a 6-well plate and were serum starved for $24 \mathrm{hrs}$. The cells were pre-incubated with C021 dihydrochloride $(0.3 \mu \mathrm{M})$ for $30 \mathrm{~min}$. The cells were then stimulated with rhCCL17/TARC $(15 \mathrm{ng} / \mathrm{ml})$ in the presence or without CCR4 receptor antagonist for $45 \mathrm{~min}$. DMSO was used as a control. (E) C021 ablates CCL17/TARC-induced activation of an NFkB-responsive promoter. Cells were transfected with the luciferase reporter plasmid with an NFKB responsive promoter and exposed to rhCCL17/TARC $(15 \mathrm{ng} / \mathrm{ml})$ in the presence or without CCR4 receptor antagonist C012 $(0.1$ or $1 \mu \mathrm{M})$ for $45 \mathrm{~min}$. DMSO was used as a control. Each bar represent the average of three independent parallels. Luciferase values were corrected for protein concentration of the samples. $P^{*} \leq 0.05$ and $P^{* *} \leq 0.01$. (F) CCL17/TARC stimulates proliferation of MCC13 cells. Cell were exposed to PBS or increasing concentrations of rhCCL17/TARC $/ 12-100 \mathrm{ng} / \mathrm{ml}$ ) and cell proliferation was measured after 24 and 48 hrs. Each bar represents the average of three independent parallels. (G) Cells were incubated for 45 min with 0.1 or $10 \mu \mathrm{M} \mathrm{C} 021$ and rhCCL17/TARC (12 or $25 \mathrm{ng} / \mathrm{ml}$ ) was subsequently added. Proliferation was monitored $24 \mathrm{hrs}$ later. $P^{*} \leq 0.05$ and $P^{* *}$ $\leq 0.01$. 
of CCR4 and CCL17/TARC between MCPyV-negative and MCPyV-positive primary cutaneous MCCs. Since immunohistochemistry is more qualitative rather than a quantitative analysis therefore, increase in CCL17/TARC levels between MCPyV-positive and -negative samples may not be visible by IHC.

Given the fact that MCC produces CCL17/TARC and expresses CCR4, we decided to investigate the effect of exogenously added CCL17/TARC on intracellular signaling pathways. Recombinant hCCL17/TARC induced the proliferation in $\mathrm{MCPyV}$-negative MCC cells, which was abolished in the presence of the CCR4 receptor antagonist. The addition of CCL17/TARC resulted in ERK1/2 phosphorylation in MCC13 cells (Figure 6). Previous studies have shown that CCL17/TARC induced chemotaxis of the mouse T-cell lymphoma cell line EL4 in a MEK1/2-ERK1/2-dependent manner [66].

We also demonstrate that CCL17/TARC activates the NF- $\kappa \mathrm{B}$ pathway in MCC13 cells. Previous studies have shown that CCL17/TARC is a NF- $\kappa \mathrm{B}$ target gene $[67,68]$, but it has not been shown that CCL17/TARC can itself activate NF- $\kappa \mathrm{B}$. CCR4-mediated MMP13 activity in colorectal cancer cells requires NF- $\kappa \mathrm{B}$ [52]. Chemokine-like factor (CKLF1), which also uses the $\mathrm{CCR} 4$ receptor, can activate the $\mathrm{NF}-\kappa \mathrm{B}$ pathway [69], and $\mathrm{NF}-\kappa \mathrm{B}$ signaling is significantly downregulated in CCR4 - macrophages [70].

In the tumor microenvironment, a high expression of CCL17/TARC and CCR4 by MCC cells may contribute to the activation of inflammatory pathways and the promotion of tumor growth and immune suppression. We found that CCL17/TARC stimulated proliferation of MCC13 cells, whereas several studies have reported that CCL17/TARC or CCL22-associated CD $4{ }^{+} \mathrm{CD} 25^{+} \mathrm{Foxp}^{+}$ increases the population in tumor-infiltrating lymphocytes (TILs), with peripheral blood lymphocytes (PBLs) being one of the reasons for impaired anti-tumor immunity in both gastric and esophageal squamous cell carcinoma $[44,45]$. It is postulated that the preferential attraction of CCR4-bearing Th2 lymphocytes may cause a shift towards a Th2-dominated cytokine microenvironment, thereby hampering the cytotoxic immune response and providing a mechanism by which neoplastic cells are able to escape from the immune system [71]. Targeting CCR4 is an emerging strategy for immunotherapy for cancer [57, 72]. Gain-of-function mutations in adult T cell lymphoma have been reported [73] and recently, Mogalizumab, a monoclonal antibody targeting CCR4 receptor has shown promising results in the treatment of relapsed adult $\mathrm{T}$ cell lymphoma patients [74-78].

Taken together, we demonstrate that MCPyV LT is linked with an altered expression of CCL17/CCR4. The expression of CCL17/TARC and CCR4 may constitute an autocrine or paracrine survival loop which contributes to the growth and survival of the tumor, and also mediates immune suppression through the recruitment of regulatory T cells. Thus, strategies based on the selective targeting of the CCL17/CCR4 axis, either by monoclonal antibodies or specific receptor antagonists, could be a therapeutic interventions for patients with MCC.
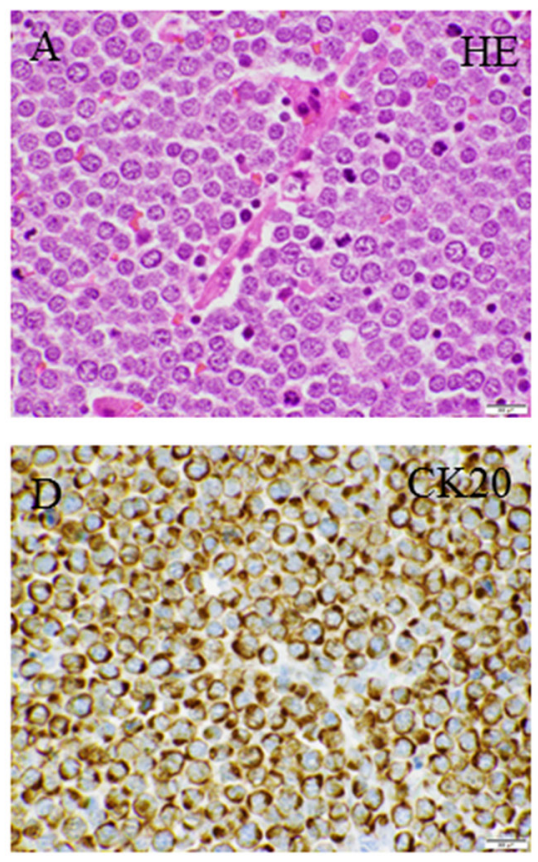
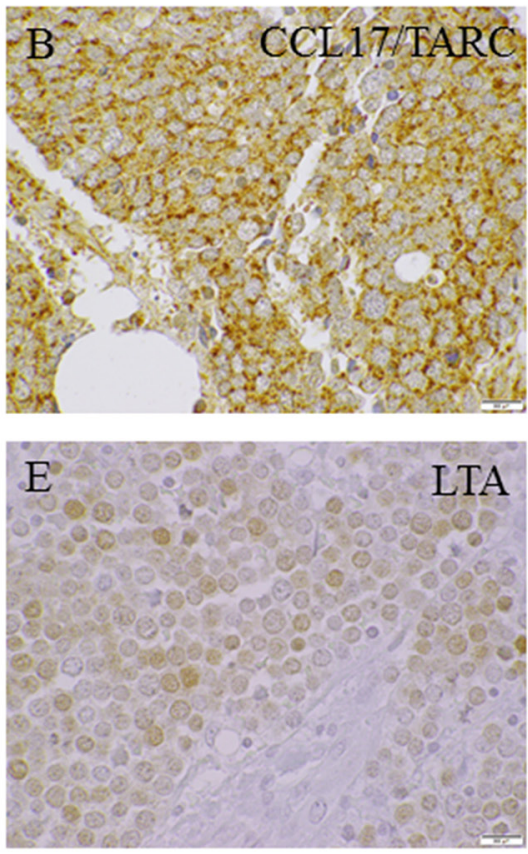
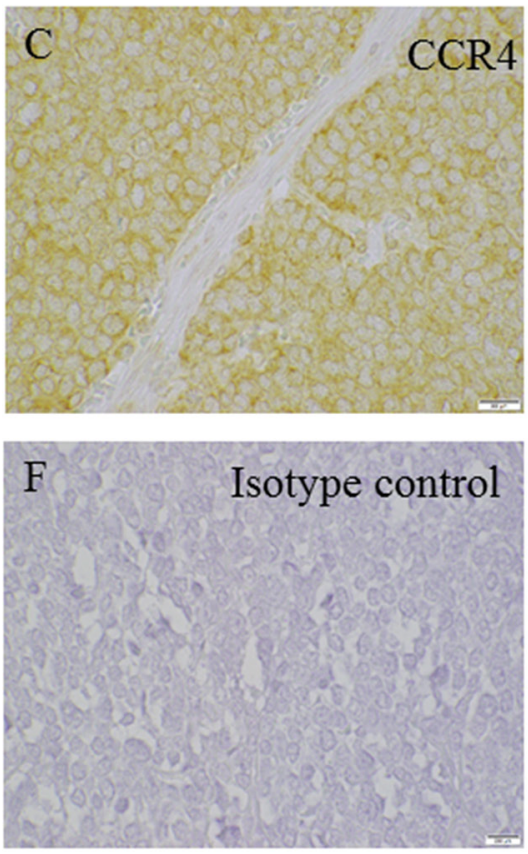

Figure 8: Immunoperoxidase staining of MCPyV-associated MCC primary tumors. (A) HE, (B) CCL17/TARC, (C) CCR4, (D) CK20, (E) LTA and (F) Isotype control. The displayed images are representative stainings from a panel of MCC primary tumors (Scale bar $=500 \mu \mathrm{m}$ ). 
Table 1: Primer sequences for full-length LT and generating truncated Large Tag transcripts

MCPyV full-length LT sequence primers

Full LT.F

5'-TACAAGCACTCCACCAAAGC-3'

Full_LT.R

5'-TCCAATTACAGCTGGCCTCT-3'

Site-directed mutagenesis primers to make MKL-1 LT

MKL-1_LTstop.F

5'-GCCATGCTGTGTACAAGTTTTAAACAGTCTCCTGTTTTGC-3'

MKL-1_LTstop.R

5'-GCAAAACAGGAGACTGTTTAAAACTTGTACACAGCATGGC-3'

Site-directed mutagenesis primers to make MKL-2 LT

MKL-2_LTstop.F

5'-GAAGACCCCTCCTCCATAGTCAAGAAAGCG-3'

MKL-2_LTstop.R

5'-CGCTTTCTTGACTATGGAGGAGGGGTCTTC-3'

Site-directed mutagenesis primers to make MS-1 LT

MS-1_LTstop.F

5'-GCCACTGCTAAATTAGGAATTTCAAGAAAAAG-3'

MS-1_LTstop.R

5'-CTTTTTCTTGAAATTCCTAATTTAGCAGTGGC-3'

\section{MATERIALS AND METHODS}

\section{Materials}

In our study, the following primary antibodies were used: i.e. monoclonal mouse MCPyV LTA (Sc-136172, Santa Cruz Biotechnologies), polyclonal rabbit CCL17/TARC (Ab182793, Abcam), polyclonal rabbit anti-CCR4 (cat.\#PA1516, Boster, USA), polyclonal rabbit ERK2 (Sc-136172, Santa Cruz Biotechnologies, Dallas, TX, USA), monoclonal rabbit keratin 20 (cat.\# 13063, Cell Signaling, Danvers, MA, USA), monoclonal rabbit Phospho-p44/42 MAPK (Erk1/2) (Thr202/Tyr204) (cat.\#4370 Cell Signaling), monoclonal rabbit p44/42 MAPK (Erk1/2) (cat.\#4695S, Cell Signaling), Phospho-NF-кB p105 (Ser933) (18E6) (cat.\#4806S, Cell Signaling) rabbit anti-GAPDH (cat.\# G9545, Sigma Aldrich, St. Louis, MO, USA) and CCR4 chemokine receptor antagonist (C 021 dihydrochloride) (cat. \#3581, Tocris Bioscience Minneapolis, MN, USA)).

\section{Plasmids}

The empty expression plasmid pcDNA3.1(+) was purchased from Invitrogen. pcDNA3-full large T-antigen (pcDNA6.MCV.cLT206.V5_CM2B4) was purchased from Addgene (Cambridge, MA, USA), while pcDNA3-MKL-1 large T-antigen, pcDNA3-MKL-2 large T-antigen and pcDNA3-MS-1 large T-antigen were constructed by sitedirected mutagenesis using the original pcDNA6.MCV. cLT206.V5_CM2B4 plasmid. pCMV2-CCL17-flag (cat.\# HG10233-M-F) expression plasmid was purchased from SinoBiological (Beijing, China). The plasmids pCCL172532+40-LUC, pCCL17-1080/+40-LUC, and pCCL17$375 /+40$-LUC containing CCL17 promoter fragments in the luciferase reporter plasmid pGL3-basic (Promega) were a kind gift from Dr. Daniel Hebenstreit [79].

\section{Cell lines and human tissue samples}

MCC13 and MKL-2 cell lines were kindly provided by Dr. Baki Akgül (University of Cologne, Germany). MCC13 is a MCPyV-negative MCC cell line, whereas MKL-2 is a MCPyV-positive MCC cell line [58, 59]. MCC13 cells were grown in RPMI-1640 with $10 \%$ FBS in the presence of $100 \mu \mathrm{g} / \mathrm{ml}$ streptomycin and 100 units/ml of penicillin, while MKL-2 cells were grown in RPMI-1640 with $20 \%$ FBS in the presence of $100 \mu \mathrm{g} /$ $\mathrm{ml}$ streptomycin and 100 units $/ \mathrm{ml}$ penicillin. Cells were kept in a humidified $\mathrm{CO}_{2}$ incubator at $37^{\circ} \mathrm{C}$. Human $\mathrm{MCC}$ tissue were obtained during 2000-2015 from the St. Olavs University Hospital Trondheim, Norway according to the ethical approval from the Regional Ethical Committee (REK NORD application number 2016/988).

\section{PCR-based site-directed mutagenesis of MCPyV truncated LT encoding plasmid}

To generate expression plasmids encoding truncated variants of MCPyV LT expressed in the viruspositive MKL-1, MKL-2 and MS-1 MCC cell lines, an oligonucleotide-directed mutagenesis was performed using the QuickChange site-directed mutagenesis kit from Stratagene (cat. no. 200518; Stratagene La Jolla, CA, USA). Plasmid pcDNA6.MCV.cLT206.V5 was used as a template to generate the plasmids pcDNA3-MKL-1 LT, pcDNA3-MKL-2 LT, pcDNA3-MS-1 LT. Table 1 shows different primers to generate truncated MKL-1, MKL-2 and MS-1 sequences from full-length LT. 


\section{Transfection}

Cells were seeded out in 6- and 12-well cell culture plates with a total number of $1.5 \times 10^{5}$ and $2 \times 10^{5}$, respectively. At the time of transfections, the cells were approximately $60-70 \%$ confluent. jetPRIME (Polyplustransfection SA, Illkirch, France) was used to transfect all plasmids according to the manufacturer's instructions. A total of $2-\mu \mathrm{g}$ per well in a 6-well plate and $800 \mathrm{ng}$ per well in a 12-well plate DNA was used to transfect cells. All experiments were performed $24 \mathrm{hrs}$ after transfection.

\section{RNA extraction}

RNA extraction was done by using RNeasy ${ }^{\circledR}$ Plus Mini kit (Qiagen, Hilden, Germany) according to the manufacturer's protocol. For RNA yield and quality, $\mathrm{A}_{260}$ ${ }_{A 280}$ and $A_{260 / A 230}$ ratios were analyzed with Nano-Drop ${ }^{\circledR}$ ND-2000 spectrophotometer (NanoDrop Technologies, ThermoFisher Scientific, Waltham, MA, USA).

\section{cDNA construction and quality control}

iScript ${ }^{\mathrm{TM}}$ cDNA Synthesis Kit (BioRad, Hercules, CA, USA) was used to make cDNA. A total of 1-2 $\mu \mathrm{g}$ RNA was used to generate cDNA according to the manufacturer's instructions. PCR with the housekeeping APRT primers (5'- CCCGAGGCTTCCTCTTTGGC-3' and 5'-CTCCCTGCCCTTAAGCGAGG-3') were used to check for genomic DNA contamination in the cDNA prep. An 800 bp fragment was obtained with genomic DNA as a template, while a $300 \mathrm{bp}$ amplicon was obtained with cDNA (76). PCR products were visualized on a $1 \%$ agarose gel stained with Gelred ${ }^{\mathrm{TM}}$ Nucleic Acid Gel Stain gel red stain (Biotium, Cambridge Bioscience, Bar Hill, UK).

\section{$\mathrm{RT}^{2}$ Profiler PCR array}

A human cytokines and receptor genes transcription was measured using the human $\mathrm{RT}^{2}$ Profiler PCR Inflammatory Cytokines and Receptors Array (PAHS011ZA, SABiosciences, Qiagen). Twenty $\mu \mathrm{l}$ cDNA were diluted to $111 \mu \mathrm{l}$ by adding $91 \mu \mathrm{l}$ of RNase-free water. One hundred and two $\mu \mathrm{l}$ were added in a $1350 \mu \mathrm{l} 2 \mathrm{x} \mathrm{RT}^{2}$ SYBR Green Mastermix according to the manufacturer's protocol. Twenty-five $\mu \mathrm{l}$ PCR components mix was added to each well of a 96-well plate. A two-step real-time PCR was initiated at $95^{\circ} \mathrm{C}(10 \mathrm{~min})$ for one cycle, and followed by alteration of $95^{\circ} \mathrm{C}(15 \mathrm{sec})$ and $60^{\circ} \mathrm{C}(1 \mathrm{~min})$ for 45 cycles by using Light Cycler 96 (Roche Diagnostics, Indianapolis, IN, USA). All data was collected from the PCR machine by Light Cycler 96 SW 1.1 software (Provided by manufacturer), and analyzed by SA Bioscience's Gene Glob PCR Array Data Analysis Web Portal. For considering a gene differentially expressed, we used a differential cut-off of 2-fold (up- or downregulated).

\section{Luciferase assays}

For luciferase assays, approximately $24 \mathrm{hrs}$ after transfection, cells were lysed in a $100 \mu 1$ Luciferase Assay Tropix Lysis solution (ThermoFisher Scientific), with 0.5 mM DTT. Cells were scraped, transferred to Eppendorf tubes and then centrifuged for 3 minutes at $12,000 \mathrm{~g}$. Twenty $\mu l$ of the supernatant was used in a 96-well microtiter plate, and a $50 \mu$ l luciferase buffer (Promega, Madison, WI, USA) was added. A Luminometer (Labsystem, Luminoscan RT) used to measure lights units. Each experiment was repeated three times with three independent parallels for each experiment, and luciferase values were corrected for protein content in each sample. The total protein concentration was measured using the MN protein quantification assay (Macherey-Nagel GmbH, Düren, Germany).

\section{Quantitative real-time PCR}

The gene expression level of CCL17/TARC was measured by real-time quantitative RT-PCR using an ABI PRISM ${ }^{\circledR} 7300$ Sequence Detection System (Applied Biosystems, Foster City, CA, USA). The expression level was measured by using a FAM-labeled TaqMan gene expression assay CCL17/TARC probe/primer (Cat. \# Hs00171074_m1), and the expression level was normalized by using a VIC/MGB probe/primer Eukaryotic 18S rRNA Endogenous Control (Cat. \#4319413E, Applied Biosystems). PCR reactions were prepared in a total volume of $25 \mu \mathrm{l}$, with a final concentration of $1 \mathrm{X} \mathrm{TaqMan}^{\circledR}$ Universal Master Mix and cDNA from $1 \mu \mathrm{g}$ total RNA.

\section{Immunoblotting}

Western blot was done by running samples in $4-12 \%$ of NuPAGE Bis-Tris Mini Gels (Invitrogen Life Technologies, Carlsbad, CA, USA) according to the manufacturer's protocol and blotted onto a $0.45 \mu \mathrm{m}$ PVDF membrane (Millipore, Billerica, MA, USA). Membrane blocking was performed by using TBS-T (TBS with $0.1 \%$ Tween-20; Sigma Aldrich) containing 5\% (w/v) dried skimmed milk for 1 hour. The protein was probed by using an appropriate primary antibody overnight at $4^{\circ} \mathrm{C}$. After washing the membrane 3 times with TBS-T, an appropriate secondary antibody was added for 1 hour at room temperature. After 2 washes with TBS-T and 2 washings with washing buffer, antigen-antibody complex was visualized by using SuperSignal ${ }^{\mathrm{TM}}$ West Pico Chemiluminescent Substrate (Cat.\#34080 Thermo Fisher Scientific, Rockford, IL, USA). Magic-Mark ${ }^{\mathrm{TM}}$ Western standard from Invitrogen Life Technologies was used to estimate the molecular mass of the detected proteins.

\section{Immunohistochemistry}

Formalin-fixed and paraffin-embedded tissue sections were deparaffinized in xylene and graded alcohols, hydrated and washed in PBS. After antigen retrieval in 
a sodium citrate buffer ( $\mathrm{pH}$ 6) in a microwave oven, the endogenous peroxidase was blocked by $0.3 \% \mathrm{H}_{2} \mathrm{O}_{2}$ for 15 min. Sections were incubated overnight at $4{ }^{\circ} \mathrm{C}$ with the primary antibody CCR4 (Abcam Cat.\#ab1699, Cambridge, UK), CCL17/TARC (Abcam Cat.\#ab182793), MCPyV-LT (Santa Cruz Biotechnology Cat.\#sc-136172) and CK20 (Roche Cat.\#790-4431). As a secondary antibody, the antirabbit-HRP SuperPicTure Polymer detection kit (87-9663, Zymed-Invitrogen, San Francisco, CA, USA) or anti-mouse EnVision-HRP (Dako, Agilent Technologies, Inc., Santa Clara, CA, USA) was used. A matched isotype control was used as a control for nonspecific background staining.

\section{MTT assay}

To measure cell proliferation, the colorimetric MTT (3-(4,5-dimethylthiazol-2-yl)-2,5-diphenyltetrazodium bromide)-assay was used [80].

\section{Statistical analysis}

The RT2 Profiler PCR Array data analysis version 3.5 (http://dataanalysis.sabiosciences.com/pcr/arrayanalysis.php) was used for inflammatory cytokines and receptor data analysis. For the analysis, the significant values were considered with a fold change/fold regulation $\geq 2$ and a p-value less than 0.05. GraphPad software was used for the statistical analysis and graphs. The sample $t$-test was used to compare differences between the experimental and control group and a $p$-value set $<0.05$. The densitometry analysis of Western blot was done by using imageJ.

\section{CONFLICTS OF INTEREST}

The authors declare no conflicts of interest.

\section{FUNDING}

This study was funded with grants from the University of Tromsø, Erna and Olav Aakre Foundation for Cancer Research Tromsø, The Olav Raagholt og Gerd Meidel Raagholt Research Foundation, Norway and Odd Fellow Research foundation, Norway.

\section{REFERENCES}

1. Heath M, Jaimes N, Lemos B, Mostaghimi A, Wang LC, Penas PF, Nghiem P. Clinical characteristics of Merkel cell carcinoma at diagnosis in 195 patients: the AEIOU features. J Am Acad Dermatol. 2008; 58:375-81. https://doi.org/10.1016/j.jaad.2007.11.020.

2. Poulsen M. Merkel-cell carcinoma of the skin. Lancet Oncol. 2004; 5:593-9. https://doi.org/10.1016/S1470-2045(04)01593-1.

3. Feng H, Shuda M, Chang Y, Moore PS. Clonal integration of a polyomavirus in human Merkel cell carcinoma. Science. 2008; 319:1096-100. https://doi.org/10.1126/science.1152586.
4. Chang Y, Moore PS. Merkel cell carcinoma: a virusinduced human cancer. Annu Rev Pathol. 2012; 7:123-44. https://doi.org/10.1146/annurev-pathol-011110-130227.

5. Samimi M, Touze A. Merkel cell carcinoma: the first human cancer shown to be associated with a polyomavirus. Presse Med. 2014; 43:e405-11. https://doi.org/10.1016/j.lpm.2014.09.008.

6. Gjoerup O, Chang Y. Update on human polyomaviruses and cancer. Adv Cancer Res. 2010; 106:1-51. https://doi.org/10.1016/S0065-230X(10)06001-X.

7. Carter JJ, Daugherty MD, Qi X, Bheda-Malge A, Wipf GC, Robinson K, Roman A, Malik HS, Galloway DA. Identification of an overprinting gene in Merkel cell polyomavirus provides evolutionary insight into the birth of viral genes. Proc Natl Acad Sci U S A. 2013; 110:127449. https://doi.org/10.1073/pnas.1303526110.

8. Tolstov YL, Pastrana DV, Feng H, Becker JC, Jenkins FJ, Moschos S, Chang Y, Buck CB, Moore PS. Human Merkel cell polyomavirus infection II. MCV is a common human infection that can be detected by conformational capsid epitope immunoassays. Int J Cancer. 2009; 125:1250-6. https://doi.org/10.1002/ijc.24509.

9. Feng H, Kwun HJ, Liu X, Gjoerup O, Stolz DB, Chang Y, Moore PS. Cellular and viral factors regulating Merkel cell polyomavirus replication. PLoS One. 2011; 6:e22468. https://doi.org/10.1371/journal.pone.0022468.

10. Wendzicki JA, Moore PS, Chang Y. Large T and small T antigens of Merkel cell polyomavirus. Curr Opin Virol. 2015; 11:38-43. https://doi.org/10.1016/j.coviro.2015.01.009.

11. Shuda M, Guastafierro A, Geng X, Shuda Y, Ostrowski SM, Lukianov S, Jenkins FJ, Honda K, Maricich SM, Moore PS, Chang Y. Merkel cell polyomavirus small T antigen induces cancer and embryonic merkel cell proliferation in a transgenic mouse model. PLoS One. 2015; 10:e142329. https://doi.org/10.1371/journal.pone.0142329.

12. Verhaegen ME, Mangelberger D, Harms PW, Vozheiko TD, Weick JW, Wilbert DM, Saunders TL, Ermilov AN, Bichakjian CK, Johnson TM, Imperiale MJ, Dlugosz AA. Merkel cell polyomavirus small $\mathrm{T}$ antigen is oncogenic in transgenic mice. J Invest Dermatol. 2015; 135:1415-24. https://doi.org/10.1038/jid.2014.446.

13. Spurgeon ME, Cheng J, Bronson RT, Lambert PF, DeCaprio JA. Tumorigenic activity of merkel cell polyomavirus $\mathrm{T}$ antigens expressed in the stratified epithelium of mice. Cancer Res. 2015; 75:1068-79. https://doi.org/10.1158/0008-5472.CAN-14-2425.

14. Verhaegen ME, Mangelberger D, Harms PW, Eberl M, Wilbert DM, Meireles J, Bichakjian CK, Saunders TL, Wong SY, Dlugosz AA. Merkel cell polyomavirus small $\mathrm{T}$ antigen initiates merkel cell carcinoma-like tumor development in mice. Cancer Res. 2017; 77:3151-7. https://doi.org/10.1158/0008-5472.CAN-17-0035.

15. Houben R, Adam C, Baeurle A, Hesbacher S, Grimm J, Angermeyer S, Henzel K, Hauser S, Elling R, Brocker 
EB, Gaubatz S, Becker JC, Schrama D. An intact retinoblastoma protein-binding site in Merkel cell polyomavirus large $\mathrm{T}$ antigen is required for promoting growth of Merkel cell carcinoma cells. Int J Cancer. 2012; 130:847-56. https://doi.org/10.1002/ijc. 26076.

16. Angermeyer S, Hesbacher S, Becker JC, Schrama D, Houben R. Merkel cell polyomavirus-positive Merkel cell carcinoma cells do not require expression of the viral small T antigen. J Invest Dermatol. 2013; 133:2059-64. https://doi.org/10.1038/jid.2013.82.

17. Shuda M, Chang Y, Moore PS. Merkel cell polyomaviruspositive Merkel cell carcinoma requires viral small T-antigen for cell proliferation. J Invest Dermatol. 2014; 134:1479-81. https://doi.org/10.1038/jid.2013.483.

18. Nagarsheth N, Wicha MS, Zou W. Chemokines in the cancer microenvironment and their relevance in cancer immunotherapy. Nat Rev Immunol. 2017; 17:559-72. https://doi.org/10.1038/nri.2017.49.

19. Zamarron BF, Chen W. Dual roles of immune cells and their factors in cancer development and progression. Int J Biol Sci. 2011; 7:651-8.

20. Grivennikov SI, Greten FR, Karin M. Immunity, inflammation, and cancer. Cell. 2010; 140:883-99. https://doi.org/10.1016/j.cell.2010.01.025.

21. Saeki H, Tamaki K. Thymus and activation regulated chemokine (TARC)/CCL17 and skin diseases. J Dermatol Sci. 2006; 43:75-84. https://doi.org/10.1016/j.jdermsci.2006.06.002.

22. Kubo T, Ichimiya S, Tonooka A, Nagashima T, Kikuchi T, Sato N. p63 induces CD4+ T-cell chemoattractant TARC/ CCL17 in human epithelial cells. J Interferon Cytokine Res. 2008; 28:725-32. https://doi.org/10.1089/jir.2008.0035.

23. Gilet J, Chang Y, Chenivesse C, Legendre B, Vorng H, Duez C, Wallaert B, Porte H, Senechal S, Tsicopoulos A. Role of CCL17 in the generation of cutaneous inflammatory reactions in Hu-PBMC-SCID mice grafted with human skin. J Invest Dermatol. 2009; 129:879-90. https://doi.org/10.1038/jid.2008.333.

24. Hirahara K, Liu L, Clark RA, Yamanaka K, Fuhlbrigge RC, Kupper TS. The majority of human peripheral blood CD4+CD25highFoxp3+ regulatory T cells bear functional skin-homing receptors. J Immunol. 2006; 177:4488-94.

25. Lim HW, Lee J, Hillsamer P, Kim CH. Human Th17 cells share major trafficking receptors with both polarized effector T cells and FOXP3 + regulatory T cells. J Immunol. 2008; 180:122-9.

26. Moens U, Seternes OM, Johansen B, Rekvig OP. Mechanisms of transcriptional regulation of cellular genes by SV40 large T- and small T-antigens. Virus Genes. 1997; 15:135-54.

27. Atwood WJ, Wang L, Durham LC, Amemiya K, Traub RG, Major EO. Evaluation of the role of cytokine activation in the multiplication of JC virus (JCV) in human fetal glial cells. J Neurovirol. 1995; 1:40-9.
28. Kim SY, Choi EC, Woo Jo Y, Henson JW, Kim HS. Transcriptional activation of JC virus early promoter by phorbol ester and interleukin-1beta: critical role of nuclear factor-1. Virology. 2004; 327:60-9. https://doi.org/10.1016/j.virol.2004.06.021.

29. Enam S, Sweet TM, Amini S, Khalili K, Del Valle L. Evidence for involvement of transforming growth factor betal signaling pathway in activation of JC virus in human immunodeficiency virus 1-associated progressive multifocal leukoencephalopathy. Arch Pathol Lab Med. 2004; 128:282-91. https:/doi.org/10.1043/1543-2165(2004)128<282:EFIOTG $>2.0 . C O ; 2$.

30. Abend JR, Imperiale MJ. Transforming growth factor-betamediated regulation of BK virus gene expression. Virology. 2008; 378:6-12. https://doi.org/10.1016/j.virol.2008.05.009.

31. Reiss Y, Proudfoot AE, Power CA, Campbell JJ, Butcher EC. CC chemokine receptor (CCR)4 and the CCR10 ligand cutaneous T cell-attracting chemokine (CTACK) in lymphocyte trafficking to inflamed skin. J Exp Med. 2001; 194:1541-7.

32. Vestergaard C, Johansen C, Christensen U, Just H, Hohwy T, Deleuran M. TARC augments TNF-alpha-induced CTACK production in keratinocytes. Exp Dermatol. 2004; 13:551-7. https://doi.org/10.1111/j.0906-6705.2004.00202.x.

33. Johansen C, Kragballe K, Westergaard M, Henningsen J, Kristiansen K, Iversen L. The mitogen-activated protein kinases p38 and ERK1/2 are increased in lesional psoriatic skin. Br J Dermatol. 2005; 152:37-42. https://doi.org/10.1111/j.1365-2133.2004.06304.x.

34. Sarvaiya PJ, Guo D, Ulasov I, Gabikian P, Lesniak MS. Chemokines in tumor progression and metastasis. Oncotarget. 2013; 4:2171-85. https://doi.org/10.18632/oncotarget.1426.

35. Starrett GJ, Marcelus C, Cantalupo PG, Katz JP, Cheng J, Akagi K, Thakuria M, Rabinowits G, Wang LC, Symer DE, Pipas JM, Harris RS, DeCaprio JA. Merkel cell polyomavirus exhibits dominant control of the tumor genome and transcriptome in virus-associated merkel cell carcinoma. MBio. 2017; 8:e02079-16. https://doi.org/10.1128/mBio.02079-16.

36. Griffiths DA, Abdul-Sada H, Knight LM, Jackson BR, Richards K, Prescott EL, Peach AH, Blair GE, Macdonald A, Whitehouse A. Merkel cell polyomavirus small $\mathrm{T}$ antigen targets the NEMO adaptor protein to disrupt inflammatory signaling. J Virol. 2013; 87:13853-67. https://doi.org/10.1128/JVI.02159-13.

37. Richards KF, Guastafierro A, Shuda M, Toptan T, Moore PS, Chang Y. Merkel cell polyomavirus $\mathrm{T}$ antigens promote cell proliferation and inflammatory cytokine gene expression. J Gen Virol. 2015; 96:3532-44. https://doi.org/10.1099/jgv.0.000287.

38. Kumai T, Nagato T, Kobayashi H, Komabayashi Y, Ueda S, Kishibe K, Ohkuri T, Takahara M, Celis E, Harabuchi Y. CCL17 and CCL22/CCR4 signaling is a strong candidate for novel targeted therapy against nasal natural killer/T-cell lymphoma. Cancer Immunol Immunother. 2015; 64:697705. https://doi.org/10.1007/s00262-015-1675-7. 
39. Niens M, Visser L, Nolte IM, van der Steege G, Diepstra A, Cordano P, Jarrett RF, Te Meerman GJ, Poppema S, van den Berg A. Serum chemokine levels in Hodgkin lymphoma patients: highly increased levels of CCL17 and CCL22. Br J Haematol. 2008; 140:527-36. https://doi.org/10.1111/j.1365-2141.2007.06964.x.

40. Takegawa S, Jin Z, Nakayama T, Oyama T, Hieshima K, Nagakubo D, Shirakawa AK, Tsuzuki T, Nakamura S, Yoshie O. Expression of CCL17 and CCL22 by latent membrane protein 1-positive tumor cells in age-related Epstein-Barr virus-associated B-cell lymphoproliferative disorder. Cancer Sci. 2008; 99:296-302. https://doi.org/10.1111/j.1349-7006.2007.00687.x.

41. Liu LB, Xie F, Chang KK, Shang WQ, Meng YH, Yu JJ, Li H, Sun Q, Yuan MM, Jin LP, Li DJ, Li MQ. Chemokine CCL17 induced by hypoxia promotes the proliferation of cervical cancer cell. Am J Cancer Res. 2015; 5:3072-84.

42. Al-haidari AA, Syk I, Jirstrom K, Thorlacius H. CCR4 mediates CCL17 (TARC)-induced migration of human colon cancer cells via RhoA/Rho-kinase signaling. Int J Colorectal Dis. 2013; 28:1479-87. https://doi.org/10.1007/s00384-013-1712-y.

43. Zhu F, Li X, Chen S, Zeng Q, Zhao Y, Luo F. Tumor-associated macrophage or chemokine ligand CCL17 positively regulates the tumorigenesis of hepatocellular carcinoma. Med Oncol. 2016; 33:17. https://doi.org/10.1007/s12032-016-0729-9.

44. Mizukami Y, Kono K, Kawaguchi Y, Akaike H, Kamimura K, Sugai H, Fujii H. CCL17 and CCL22 chemokines within tumor microenvironment are related to accumulation of Foxp3+ regulatory $\mathrm{T}$ cells in gastric cancer. Int J Cancer. 2008; 122:2286-93. https://doi.org/10.1002/ijc.23392.

45. Maruyama T, Kono K, Izawa S, Mizukami Y, Kawaguchi Y, Mimura K, Watanabe M, Fujii H. CCL17 and CCL22 chemokines within tumor microenvironment are related to infiltration of regulatory $\mathrm{T}$ cells in esophageal squamous cell carcinoma. Dis Esophagus. 2010; 23:422-9. https://doi.org/10.1111/j.1442-2050.2009.01029.x.

46. Liu W, Wei X, Li L, Wu X, Yan J, Yang H, Song F. CCR4 mediated chemotaxis of regulatory $\mathrm{T}$ cells suppress the activation of T cells and NK cells via TGFbeta pathway in human non-small cell lung cancer. Biochem Biophys Res Commun. 2017; 488:196-203. https://doi.org/10.1016/j.bbrc.2017.05.034.

47. Moens U, Calvignac-Spencer S, Lauber C, Ramqvist T, Feltkamp MCW, Daugherty MD, Verschoor EJ, Ehlers B, Ictv Report C. ICTV virus taxonomy profile: polyomaviridae. J Gen Virol. 2017; 98:1159-60. https://doi.org/10.1099/jgv.0.000839.

48. Messeguer X, Escudero R, Farre D, Nunez O, Martinez J, Alba MM. PROMO: detection of known transcription regulatory elements using species-tailored searches. Bioinformatics. 2002; 18:333-4.

49. Nakayama T, Hieshima K, Nagakubo D, Sato E, Nakayama M, Kawa K, Yoshie O. Selective induction of Th2-attracting chemokines CCL17 and CCL22 in human B cells by latent membrane protein 1 of Epstein-Barr virus. J Virol. 2004; 78:1665-74.

50. Monick MM, Powers LS, Hassan I, Groskreutz D, Yarovinsky TO, Barrett CW, Castilow EM, Tifrea D, Varga SM, Hunninghake GW. Respiratory syncytial virus synergizes with Th2 cytokines to induce optimal levels of TARC/CCL17. J Immunol. 2007; 179:1648-58.

51. Ueda R. Clinical Application of Anti-CCR4 Monoclonal Antibody. Oncology. 2015; 89:16-21. https://doi.org/10.1159/000431059.

52. Ou B, Zhao J, Guan S, Feng H, Wangpu X, Zhu C, Zong Y, Ma J, Sun J, Shen X, Zheng M, Lu A. CCR4 promotes metastasis via ERK/NF-kappaB/ MMP13 pathway and acts downstream of TNF-alpha in colorectal cancer. Oncotarget. 2016; 7:47637-49. https://doi.org/10.18632/oncotarget.10256.

53. Li JY, Ou ZL, Yu SJ, Gu XL, Yang C, Chen AX, Di GH, Shen ZZ, Shao ZM. The chemokine receptor CCR4 promotes tumor growth and lung metastasis in breast cancer. Breast Cancer Res Treat. 2012; 131:837-48. https://doi.org/10.1007/s10549-011-1502-6.

54. Olkhanud PB, Baatar D, Bodogai M, Hakim F, Gress R, Anderson RL, Deng $\mathrm{J}$, $\mathrm{Xu} \mathrm{M}$, Briest $\mathrm{S}$, Biragyn A. Breast cancer lung metastasis requires expression of chemokine receptor CCR4 and regulatory T cells. Cancer Res. 2009; 69:5996-6004. https://doi.org/10.1158/0008-5472.CAN-08-4619.

55. Nakamura ES, Koizumi K, Kobayashi M, Saitoh Y, Arita Y, Nakayama T, Sakurai H, Yoshie O, Saiki I. RANKL-induced CCL22/macrophage-derived chemokine produced from osteoclasts potentially promotes the bone metastasis of lung cancer expressing its receptor CCR4. Clin Exp Metastasis. 2006; 23:9-18. https://doi.org/10.1007/s10585-006-9006-1.

56. Lee JH, Cho YS, Lee JY, Kook MC, Park JW, Nam BH, Bae JM. The chemokine receptor CCR4 is expressed and associated with a poor prognosis in patients with gastric cancer. Ann Surg. 2009; 249:933-41. https://doi.org/10.1097/SLA.0b013e3181a77ccc.

57. Ishida T, Ueda R. CCR4 as a novel molecular target for immunotherapy of cancer. Cancer Sci. 2006; 97:1139-46. https://doi.org/10.1111/j.1349-7006.2006.00307.x.

58. Leonard JH, Ramsay JR, Kearsley JH, Birrell GW. Radiation sensitivity of Merkel cell carcinoma cell lines. Int J Radiat Oncol Biol Phys. 1995; 32:1401-7. https://doi.org/10.1016/0360-3016(94)00610-W.

59. Shuda M, Feng H, Kwun HJ, Rosen ST, Gjoerup O, Moore PS, Chang Y. T antigen mutations are a human tumor-specific signature for Merkel cell polyomavirus. Proc Natl Acad Sci U S A. 2008; 105:16272-7. https://doi.org/10.1073/pnas.0806526105.

60. Figenschau Y, Knutsen G, Shahazeydi S, Johansen O, Sveinbjornsson B. Human articular chondrocytes express 
functional leptin receptors. Biochem Biophys Res Commun. 2001; 287:190-7. https://doi.org/10.1006/bbrc.2001.5543.

61. Klein A, Sagi-Assif O, Meshel T, Telerman A, Izraely S, Ben-Menachem S, Bayry J, Marzese DM, Ohe S, Hoon DSB, Erez N, Witz IP. CCR4 is a determinant of melanoma brain metastasis. Oncotarget. 2017; 8:31079-91. https://doi.org/10.18632/oncotarget.16076.

62. Shoda T, Futamura K, Kobayashi F, Saito H, Matsumoto $\mathrm{K}$, Matsuda A. Expression of thymus and activationregulated chemokine (TARC) by human dermal cells, but not epidermal keratinocytes. J Dermatol Sci. 2014; 76:90-5. https://doi.org/10.1016/j.jdermsci.2014.08.009.

63. McCully ML, Moser B. The human cutaneous chemokine system. Front Immunol. 2011; 2:33. https://doi.org/10.3389/fimmu.2011.00033.

64. Fujimoto S, Uratsuji H, Saeki H, Kagami S, Tsunemi Y, Komine M, Tamaki K. CCR4 and CCR10 are expressed on epidermal keratinocytes and are involved in cutaneous immune reaction. Cytokine. 2008; 44:172-8. https://doi.org/10.1016/j.cyto.2008.07.472.

65. Stutte S, Quast T, Gerbitzki N, Savinko T, Novak N, Reifenberger J, Homey B, Kolanus W, Alenius H, Forster I. Requirement of CCL17 for CCR7- and CXCR4-dependent migration of cutaneous dendritic cells. Proc Natl Acad Sci U S A. 2010; 107:8736-41. https://doi.org/10.1073/pnas.0906126107.

66. Moroi Y, Yu B, Urabe K, Koga T, Nakahara T, Dainichi T, Uchi H, Furue M. Effects of MAPK inhibitors on CCR4mediated chemotaxis against thymus and activationregulated chemokine (TARC/CCL17). J Dermatol Sci. 2004; 36:186-8. https://doi.org/10.1016/j.jdermsci.2004.08.013.

67. Berin MC, Eckmann L, Broide DH, Kagnoff MF. Regulated production of the $\mathrm{T}$ helper 2-type T-cell chemoattractant TARC by human bronchial epithelial cells in vitro and in human lung xenografts. Am J Respir Cell Mol Biol. 2001; 24:382-9. https://doi.org/10.1165/ajrcmb.24.4.4360.

68. Bouffi C, Rochman M, Zust CB, Stucke EM, Kartashov A, Fulkerson PC, Barski A, Rothenberg ME. IL-33 markedly activates murine eosinophils by an NF-kappaB-dependent mechanism differentially dependent upon an IL-4-driven autoinflammatory loop. J Immunol. 2013; 191:4317-25. https://doi.org/10.4049/jimmunol.1301465.

69. Li G, Li GY, Wang ZZ, Ji HJ, Wang DM, Hu JF, Yuan YH, Liu G, Chen NH. The chemokine-like factor 1 induces asthmatic pathological change by activating nuclear factorkappaB signaling pathway. Int Immunopharmacol. 2014; 20:81-8. https://doi.org/10.1016/j.intimp.2014.02.014.

70. Ness TL, Ewing JL, Hogaboam CM, Kunkel SL. CCR4 is a key modulator of innate immune responses. J Immunol. 2006; 177:7531-9.

71. Vermeer $\mathrm{MH}$, Dukers DF, ten Berge RL, Bloemena E, Wu L, Vos W, de Vries E, Tensen CP, Meijer CJ,
Willemze R. Differential expression of thymus and activation regulated chemokine and its receptor CCR4 in nodal and cutaneous anaplastic large-cell lymphomas and Hodgkin's disease. Mod Pathol. 2002; 15:838-44. https://doi.org/10.1097/01.MP.0000021006.53593.B0.

72. Bayry J, Tartour E, Tough DF. Targeting CCR4 as an emerging strategy for cancer therapy and vaccines. Trends Pharmacol Sci. 2014; 35:163-5. https://doi.org/10.1016/j.tips.2014.02.003.

73. Nakagawa M, Schmitz R, Xiao W, Goldman CK, Xu W, Yang Y, Yu X, Waldmann TA, Staudt LM. Gain-of-function CCR4 mutations in adult $\mathrm{T}$ cell leukemia/lymphoma. J Exp Med. 2014; 211:2497-505. https://doi.org/10.1084/jem.20140987.

74. Yamamoto K, Utsunomiya A, Tobinai K, Tsukasaki K, Uike N, Uozumi K, Yamaguchi K, Yamada Y, Hanada $\mathrm{S}$, Tamura K, Nakamura S, Inagaki H, Ohshima K, et al. Phase I study of KW-0761, a defucosylated humanized anti-CCR4 antibody, in relapsed patients with adult T-cell leukemia-lymphoma and peripheral T-cell lymphoma. J Clin Oncol. 2010; 28:1591-8. https://doi.org/10.1200/JCO.2009.25.3575.

75. Ishida $\mathrm{T}$, Joh $\mathrm{T}$, Uike $\mathrm{N}$, Yamamoto $\mathrm{K}$, Utsunomiya A, Yoshida S, Saburi Y, Miyamoto T, Takemoto S, Suzushima H, Tsukasaki K, Nosaka K, Fujiwara H, et al. Defucosylated anti-CCR4 monoclonal antibody (KW0761) for relapsed adult T-cell leukemia-lymphoma: a multicenter phase II study. J Clin Oncol. 2012; 30:837-42. https://doi.org/10.1200/JCO.2011.37.3472.

76. Ogura $\mathrm{M}$, Ishida $\mathrm{T}$, Hatake $\mathrm{K}$, Taniwaki $\mathrm{M}$, Ando $\mathrm{K}$, Tobinai K, Fujimoto K, Yamamoto K, Miyamoto T, Uike N, Tanimoto M, Tsukasaki K, Ishizawa K, et al. Multicenter phase II study of mogamulizumab (KW-0761), a defucosylated anti-cc chemokine receptor 4 antibody, in patients with relapsed peripheral T-cell lymphoma and cutaneous T-cell lymphoma. J Clin Oncol. 2014; 32:115763. https://doi.org/10.1200/JCO.2013.52.0924.

77. Solari R, Pease JE. Targeting chemokine receptors in disease--a case study of CCR4. Eur J Pharmacol. 2015; 763:169-77. https://doi.org/10.1016/j.ejphar.2015.05.018.

78. Tobinai K, Takahashi T, Akinaga S. Targeting chemokine receptor CCR4 in adult T-cell leukemia-lymphoma and other T-cell lymphomas. Curr Hematol Malig Rep. 2012; 7:235-40. https://doi.org/10.1007/s11899-012-0124-3.

79. Maier E, Wirnsberger G, Horejs-Hoeck J, Duschl A, Hebenstreit D. Identification of a distal tandem STAT6 element within the CCL17 locus. Hum Immunol. 2007; 68:986-92. https://doi.org/10.1016/j.humimm.2007.10.012.

80. Mosmann T. Rapid colorimetric assay for cellular growth and survival: application to proliferation and cytotoxicity assays. J Immunol Methods. 1983; 65:55-63. 